\title{
Triassic depositional systems of the northern North Sea - an alternative interpretation from cores
}

\author{
Kjell-Sigve Lervik ${ }^{1}$ \\ ${ }^{1}$ Equinor ASA, NO-4035 Stavanger (retired) \\ E-mail corresponding author (Kjell-Sigve Lervik): kjellsigvelervik@gmail.com
}

Keywords:

- Triassic

- Clastic wedges

- Deltaic

- Standing water

- Marine incursions

Received:

13. October 2020

Accepted:

20. May 2021

Published online:

19. July 2021
Since the early exploration of the northern North Sea, Triassic sediments have been assigned to terrestrial depositional environments. Evaluation of core data from approximately one hundred wells in the Norwegian and UK sectors of the northern North Sea $\left(58^{\circ}-62^{\circ} \mathrm{N}\right)$, has challenged this interpretation. The sediments of the Smith Bank and Teist formations filled the deepest, syn-rift parts of the basin which in Early Triassic time were the areas closest to the Norwegian mainland, after which the centres of major subsidence shifted farther west. The mudstones of the Smith Bank and Alke formations formed as subaqueous, distal, fine-grained sediments in front of the proximal sand systems of the Lunde and Skagerrak formations. The latter accumulated as two major clastic wedges of deltaic sands derived from major valley systems emerging from the Sognefjord and Hardangerfjord/Boknfjord areas. Standing water was present during progradation of the depositional cones from the east. The depositional pattern was: alluvial to deltaic plain, delta front, subaqueous. Smaller volumes of sediment were shed off the western margin of the basin. The validity of the direct and indirect indicators of standing bodies of water, such as the rare marine and brackish-water fossils, laminae of micritic carbonate, clasts of finely laminated micritic limestone, subaqueous mass flows, wave ripples, intervals of mudstone with high GR readings correlated over semi-regional and regional areas, pyrite, possible submerged lacustrine sand flats and sabkha deposits, as well as the marine incursions into the central part of the basin during deposition of the Lunde and Skagerrak formations, are discussed.

\section{Introduction}

Since the early exploration of the northern North Sea, the red-coloured sediments of the Triassic there have been interpreted as representing continental depositional environments, a conclusion partly inherited from the Triassic of the British mainland where this is accepted. In the northern North Sea, Triassic depositional environments have been assessed mainly on descriptions of cuttings, wireline log patterns and the red colour of the sediments (Vollset \& Doré, 1984; Steel \& Ryseth, 1990; Nystuen \& Fält, 1995; Fisher \& Mudge, 1998). Few authors have presented facies analyses of cored sections, except for

Lervik, K.-S- 2021: Triassic depositional systems of the northern North Sea - an alternative interpretation from cores. Norwegian Journal of Geology 101, 202110. https://dx.doi.org/10.17850/njg101-2-5 .

(C) Copyright the authors.

This work is licensed under a Creative Commons Attribution 4.0 International License. 
Nystuen \& Fält (1995) and Nystuen et al. (2014), who discussed depositional environments based on cores from the Lunde Formation reservoirs. The red sediments of the Triassic have commonly been the deepest target for exploration wells in the northern North Sea, causing Triassic strata to be little cored. Several authors have noted the great thickness of Triassic sediments in the northern North Sea (Lervik et al., 1989; Steel \& Ryseth, 1990; Frostick et al., 1992), up to $2 \mathrm{~km}$ and thickest in the east (Olsen, 1983; Ramberg \& Morgan, 1984; Lervik et al., 1989; Færseth, 1996), related to syn-rift depocentres which developed in Early Triassic time along the present Norwegian coast (Fig. 1).

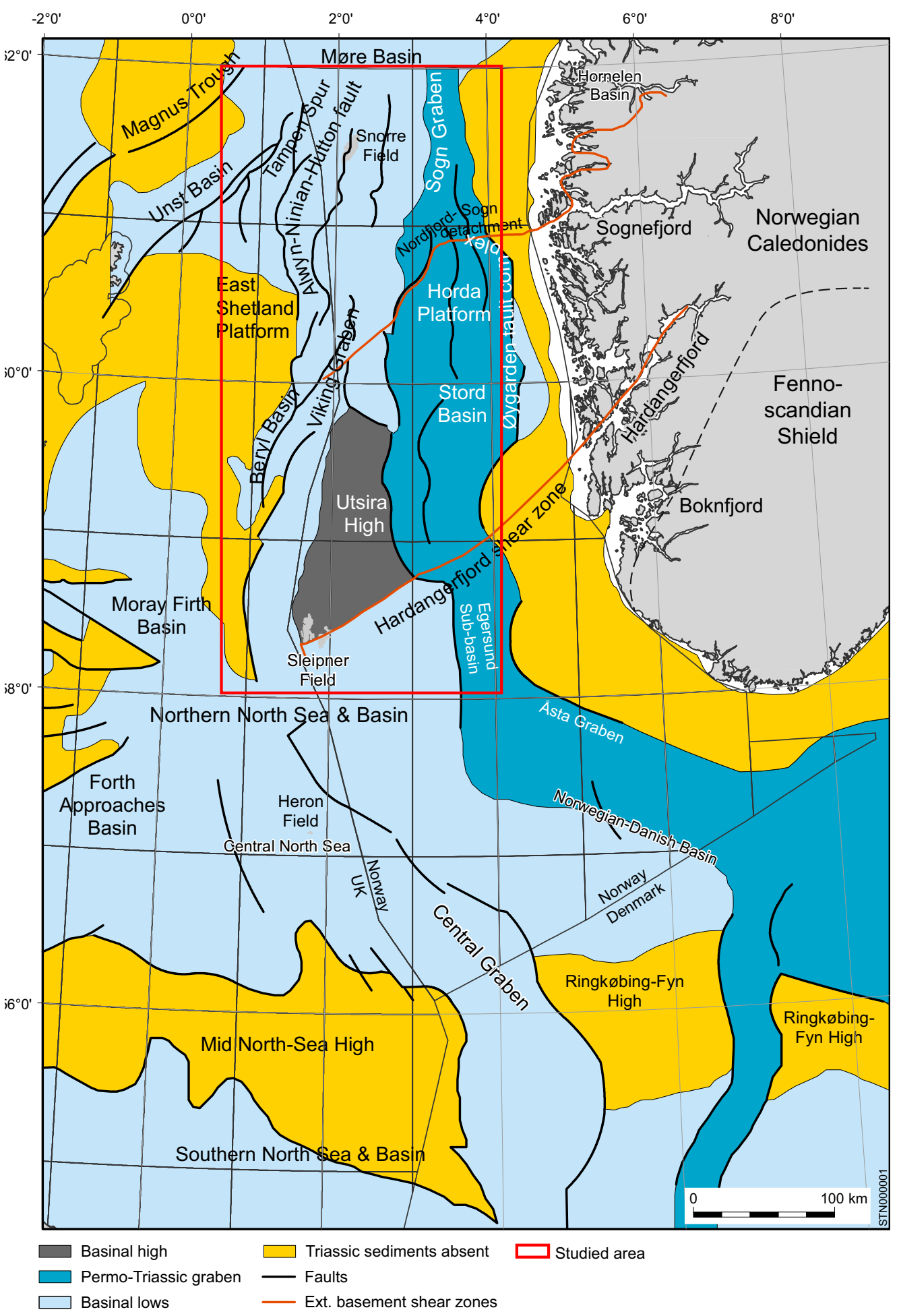

Figure 1. Structural elements map of the central and northern North Sea (modified after Lervik, 2006, p. 97, fig. 3). 
The Triassic strata of the northern North Sea $\left(58^{\circ}-62^{\circ} \mathrm{N}\right)$, both Norwegian and UK sectors, are reexamined herein using all well cores available. These cores have been logged and interpreted to erect facies descriptions, ascertain depositional environments and suggest basin configurations and patterns of sediment infill. This has revealed that the grain size of the sandstones is generally less than coarse grained, which does not support some previous interpretations that alluvial fans were the major depositional systems. Also, debrites typical of fan systems are lacking and it is here suggested that major fluvio-deltaic systems rather than fan systems were the dominant environments. A comparison is made to the Gascoyne Delta of Western Australia, an ephemeral river system dominated by seasonal flooding. This study of cores and other well data strongly suggests that subaqueous depositional environments were present along the western parts of the basin, in front of and laterally to river mouths and deltas, during deposition of the Lomvi, Alke, Lunde and Skagerrak formations. These standing bodies of water were likely mainly lacustrine, but there are also some indications that they were marine at times.

\section{Objectives}

This article is in two parts. The first part reviews the new core-based interpretations of the Lomvi, Alke, Lunde and Skagerrak formations; facies descriptions are followed by interpretations of the depositional environments, basin configurations and sediment-infill patterns; the overall conclusion is that alluvio-deltaic depositional systems prograded into standing bodies of water. The second part of the article is organised as a discussion of the evidence for the proposed standing bodies of water: What are the criteria for their existence? Were they lacustrine, periodically marine or fully marine? Did tidal currents influence the depositional system? The article aims to present a new model for the depositional systems of the Triassic of the northern North Sea, as well as to suggest multiple hypotheses and generate discussion.

\section{Database}

The stratigraphy of all released exploration wells in the Norwegian and UK sectors was re-examined. A total of 419 wells which penetrated Triassic strata have been subdivided according to the latest lithostratigraphic nomenclature: 234 wells in the Norwegian sector and 185 wells in the UK. In the Norwegian sector south of $62^{\circ} \mathrm{N}, 80$ exploration wells have a total of $4591 \mathrm{~m}$ of Triassic core (source: http://factpages.npd.no/factpages/); the longest core is $355.5 \mathrm{~m}$ (NO 34/8-4S). Twelve wells have core lengths of less than $10 \mathrm{~m}, 39$ wells have $10-50 \mathrm{~m}, 16$ wells have $50-100 \mathrm{~m}$ while 13 wells have more than $100 \mathrm{~m}$. In the UK sector, the study has used cores from 32 released exploration wells mainly in the northernmost part of the northern North Sea (https://www.bgs.ac.uk/data/offshoreWells/wells.cfc?method=searchWells) to supplement interpretations based on data in the Norwegian sector.

All wells with cored intervals were recorded and core intervals were positioned according to their stratigraphic intervals. Selected cored intervals were chosen to illustrate the depositional interpretations. In the UK sector, cores were strategically chosen from wells that would aid the discussion of the overall depositional setting. The wells penetrating the Teist, Lomvi and Alke formations have relatively few cored intervals and so interpretation of those intervals may not be as representative as in the well-cored Lunde Formation. Data point coverage of the Lunde Formation is sufficient to draw a Lunde palaeogeographic map. The Skagerrak Formation has few thick successions (due to Jurassic doming and erosion) and few cored sections. 


\section{Core description and facies interpretation methods.}

Well GB 211/13-1 has been chosen as the key well to demonstrate the description and interpretation of the Triassic facies of the northern North Sea. Four cores there have allowed interpretation of depositional environments of the Lunde Formation. A traditional systematic core study of the Lunde succession in well GB 211/13-1 was presented in Lervik (1983) using the method for the facies analysis of Cant \& Walker (1976). Such an extensive analysis of the cores included in that paper was too detailed to be presented here.

Facies analyses of cores of key well GB 211/13-1 should clearly demonstrate the difference of the subaerial and subaqueous environments, as tabulated and illustrated below. Cores from other wells (Table 1) have been interpreted and used for regional control. Often, sedimentological publications are based on wells which are closely spaced, have frequent cores and where biological data have been the basis for dating. This gives control on where in the succession the core material belongs and makes it possible to make sedimentological correlations and interpretations with relatively high confidence. The Triassic strata discussed here are different: core coverage is sparse and fewer wells have penetrated the Triassic succession. Few wells have penetrated Triassic sections with dating based on fossils or biostratigraphical information. Therefore, it is generally not possible to determine where in

Table 1. Core intervals from key wells (wells referred to in this work and marked with red colour on Fig. 2A).

\begin{tabular}{|c|c|c|c|c|c|c|c|}
\hline Well & Core (m) & Teist Fm. & Lomvi Fm. & Alke Fm. & $\begin{array}{l}\text { Alke sst } \\
\text { unit }\end{array}$ & Lunde Fm. & Skagerrak Fm. \\
\hline GB 210/04- 1 & 16.3 & 16.3 & & & & & \\
\hline GB 211/07a-2 & 11.6 & & & & & 11.6 & \\
\hline GB 211/08a-2 & 36.2 & & & & & 36.2 & \\
\hline GB 211/11b- 4 & 4.0 & & & & & 4.0 & \\
\hline GB 211/13-1 & 73.9 & 9.1 & & & & 64.8 & \\
\hline GB 211/26-1 & 18.3 & & & & & 18.3 & \\
\hline GB 211/26-3 & 58.2 & & & & & 58.2 & \\
\hline GB 220/26-2 & 15.5 & 15.5 & & & & & \\
\hline NO $15 / 9-17$ & 53.1 & & & 13.9 & & & 39.2 \\
\hline NO $15 / 9-9$ & 107.0 & & & & & & 107.0 \\
\hline NO $16 / 7-4$ & 96.6 & & & & & & 96.6 \\
\hline NO $31 / 2-4 R$ & 8.4 & 8.4 & & & & & \\
\hline NO $31 / 4-3$ & 3.2 & 3.2 & & & & & \\
\hline NO $34 / 10-13$ & 4.0 & 4.0 & & & & & \\
\hline NO $34 / 4-1$ & 89.9 & & & & & 89.9 & \\
\hline NO 34/4-C-6H & 485.7 & & & & 15.0 & 470.7 & \\
\hline NO $34 / 7-1$ & 219.8 & & & & & 219.8 & \\
\hline NO $34 / 7-6$ & 57.2 & & 18.5 & & & 38.7 & \\
\hline NO $34 / 8-4 S$ & 355.5 & & 27.0 & & & 328.5 & \\
\hline NO $6201 / 11-1$ & 47.5 & & & & & 47.5 & \\
\hline Total & 1761.9 & 56.5 & 45.5 & 13.9 & 15,0 & 1298.3 & 242.8 \\
\hline
\end{tabular}


the Triassic stages each core is located. Cores of well GB 211/13-1 are located in the lower part of the Lunde Formation just above the transition from the Alke Formation and the location of the cores within the overall stratigraphy is therefore determined with confidence based on this overall lithostratigraphic pattern. This is the case for the core sections of the wells presented here - their intervals in the Triassic succession are determined based on similar lithostratigraphic criteria.

No cores are available from the lowest formation in the Triassic (Smith Bank Formation) in Norwegian waters, so the discussion here begins with the Teist Formation. For Lower and Middle Triassic strata, wells with cored sections are sparse. A structural elements map with focus on Triassic rocks is presented in Fig. 1. Fig. 2A shows wells which have been included in this work. Key wells are marked in red.

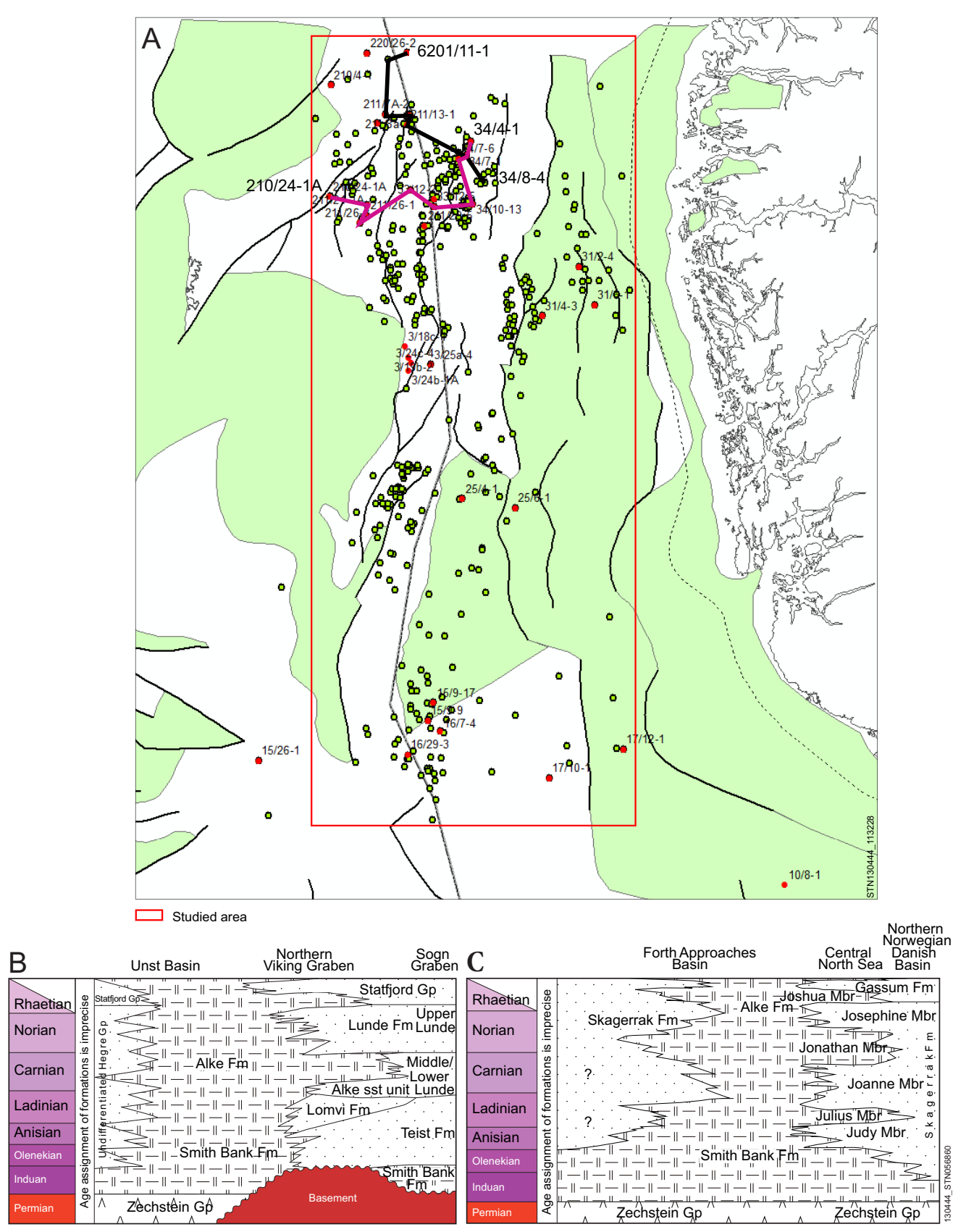

Figure 2. (A) Location of wells included in this study. Wells referred to in this publication are marked in red. Reference is made to figure 1 for colour on map. $(B, C)$ are lithostratigraphic schemes for the northern and southernmost parts of the studied area. 


\section{Facies discussion and environmental interpretation of lithostratigraphic units}

Lervik (2006) revised the Triassic lithostratigraphic scheme for the northern North Sea (Deegan \& Scull, 1977; Vollset \& Doré, 1984; Goldsmith et al., 1995). The scope of this article is to update and revise the Triassic depositional environments, given that abundant new well data have become available in the last 15 years or so. The description and discussion of the Lunde Formation defined by Vollset \& Doré (1984) had originally a comment that a lower, around $300 \mathrm{~m}$-thick sequence of brick-red to brown calcareous claystone was easily recognisable and may eventually be separated out and assigned formation status. More wells drilled showed that this fine-grained unit is an important interval in the Triassic succession. Nystuen et al. (1989) subdivided the Lunde Formation into three informal units (lower, middle and upper) where lower and middle were fine-grained intervals. Lervik (2006) revised the Triassic lithostratigraphy and formalised the lower and middle units as the Alke Formation. In this work (discussed below) an informal sandstone unit is suggested within the Alke Formation. Further work is needed in order to formalise the suggested unit. Fig. 2B, C show the lithostratigraphic units in a basin fill context, including the abandoned informal sub-division of the Lunde Formation.

\section{Teist Formation}

The early brief description of the Teist Formation, that it consists of multiple sandy intervals with intervening mudstones and siltstones, was given by Vollset \& Doré (1984). More than 30 wells have drilled into the Teist Formation in the northern North Sea (Lervik, 2006, p.104, fig. 8), but few after 2006. Six wells (GB 210/4-1, GB 211/13-1, GB 220/26-2, NO 31/2-4, NO 34/10-13 and NO 31/4-3) have short cores (Table 1). Sandy and muddy cuttings material and wireline-log patterns form the basis for interpreting the depositional environment of the Teist Formation. On the basis of seismic data, Steel \& Ryseth (1990) assigned the Teist Formation as a major part of the syn-rift infill of the eastern depocentre.

Previous interpretation. Vollset \& Doré (1984) interpreted the Teist Formation to be of continental origin. The sandstone intervals were said to include both fluvial and aeolian deposits. The muddy lithologies were assigned to overbank and lacustrine environments. Interpretation by Lervik (2006) that the Teist Formation reflects the migrating belts of ephemeral channels of a fluvial system is consistent with Vollset \& Doré (1984). There are no new cores to change the interpretation by Lervik (2006); the Teist Formation is not evaluated further here.

\section{Lomvi Formation}

A distribution pattern for the Lomvi Formation in the Northern North Sea Basin was suggested by Lervik (2006, p. 106, fig. 9). However, the three easternmost wells have been re-evaluated and it is now suggested that there are no true examples of the Lomvi Formation in the sandstone-dominated succession of the eastern part of the basin. The Formation is therefore present only in the central part of the basin. Few wells have cored the Formation and only two wells (NO 34/7-6 and NO 34/8-4S) with a total of $45.5 \mathrm{~m}$ of cores have been available for this study (Table 1). The $18.5 \mathrm{~m}$ cored section of well NO 34/7-6 shows a succession of red-stained, very fine to fine sandstones organised in poorly defined, upward-fining, facies successions (Fig. 3A). It is not possible to detect any original sedimentary structures, perhaps due to rapid deposition, destruction by biogenic activity or diagenesis. 


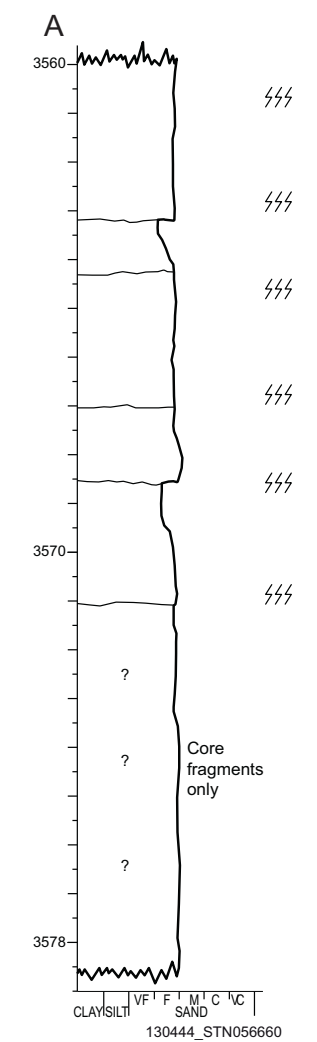

B
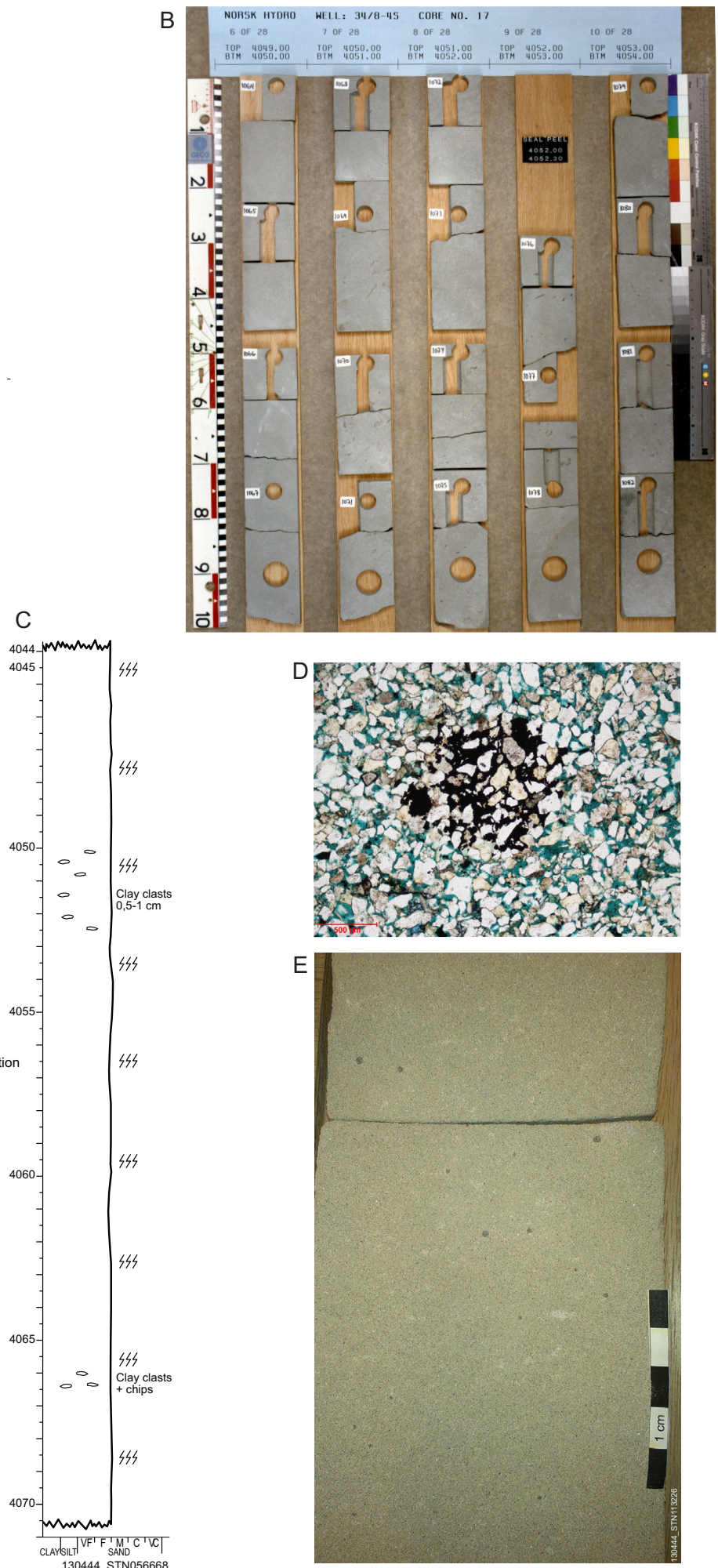

Legend:

\Planar, parallel, high-angle bedding/laminatio

Trough cross bedding

= Horizontal parallel lamination

C Current-ripple lamination

ح Wave ripples

M. Massive/structureless sandstone

Clay clasts

0 Massive, pebbly sandstone

Bioturbated

Figure 3. Strata from the Lomvi Formation. (A) Litholog interpreted to show a totally bioturbated fine-grained sandstone (3560-3578.5 m (core 13) of well NO 34/7-6). (B) Core photo showing an example of the sedimentary succession of well NO 34/8-4S (4049-4054 m (core 17)). (C) Litholog interpreted to be totally bioturbated fine grained sandstone with intervals of clay clasts/chips (4044-4071 m (core 17) of well NO 34/8-4S). (D) Microscope photo of pyrite (black colour in centre of photo) in fine-grained sandstone (well NO 34/8-4S at $4064.25 \mathrm{~m}$ ). (E) Small nodules of pyrite (dark spots) in massive sandstone (well NO 34/8-4S at $4048.5 \mathrm{~m}$ ). 
The cored succession of the Lomvi Formation of well NO 34/8-4S (Fig. 3B, C) is a monotonous interval of grey, very fine to fine-grained sandstone. Only some poorly defined horizontal laminae are observed throughout the sandstone. Millimetre-size chips of clay occur in certain intervals. The sandstone is variably mottled with indistinct, indeterminate burrows. The cored interval has here been interpreted as extensively bioturbated, but the massive appearance might be due to lack of original sedimentary structures rather than bioturbation. Core inspection as well as petrographic analyses have shown the presence of pyrite nodules, possibly reworked (Fig. 3D, E). The Lomvi succession in well NO 6201/11-1 shows a characteristic blocky gamma-ray log pattern, indicating that it is sand-rich throughout the interval (Fig. 4A), a pattern similar to the wireline log motif in other wells, e. g. NO 34/7-6.
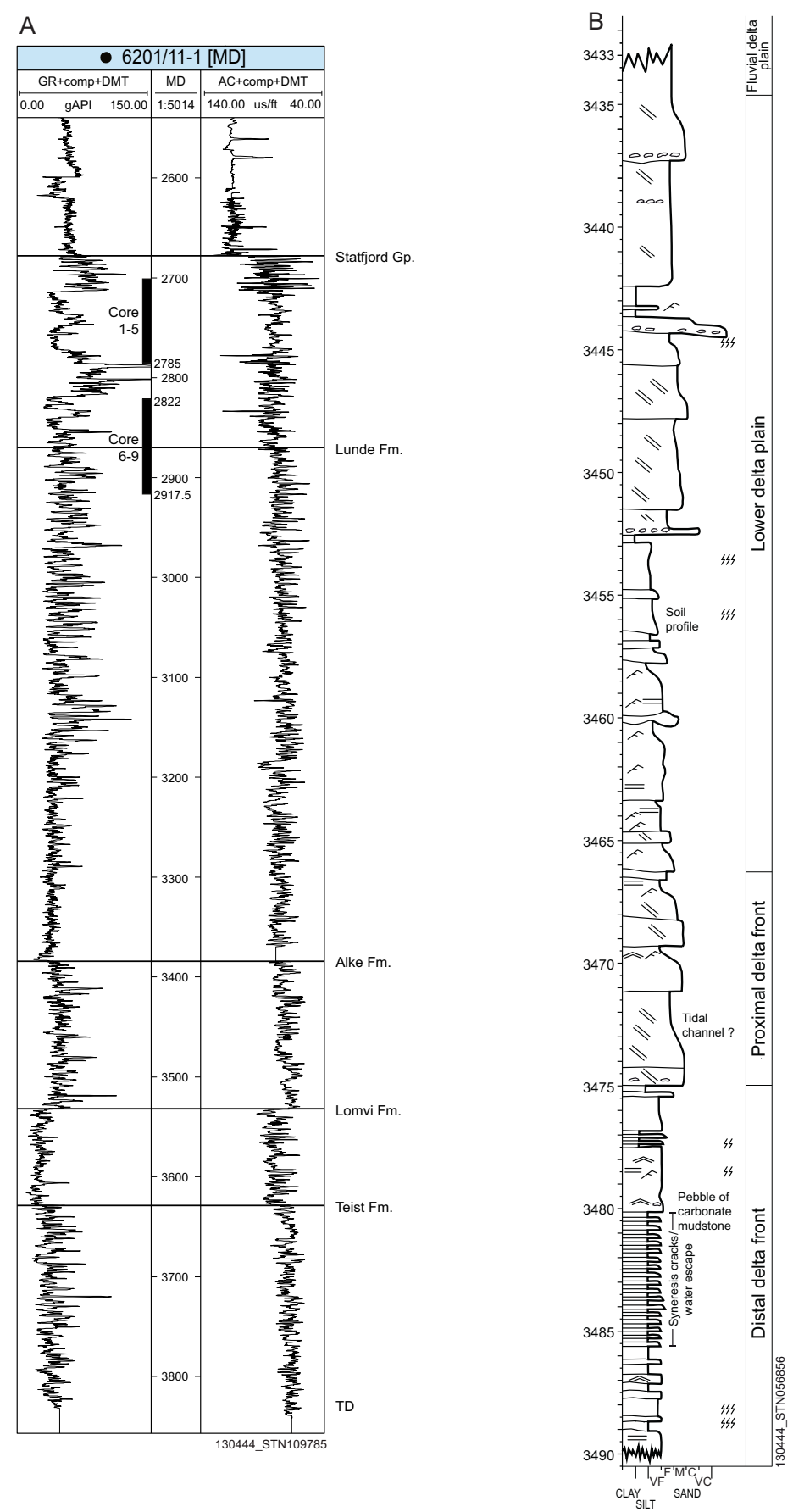

Figure 4. (A) Composite log of well NO 6201/11-1 from top Statfjord Group to total depth (TD) to show the Triassic lithostratigraphy in the northernmost part of the basin as well as the characteristic blocky gamma ray log pattern of the Lomvi Formation, indicating that it is sand-rich throughout the interval. (B) Litholog of the Alke sequence where the cored interval 3435-3490 m of well NO 34/4-C-6H has been sub-divided into deltaic sub-environments. Note the presence of synaeresis cracks at 3480-3486 m. Legend for litholog in Fig. 3. 
Previous interpretation. Vollset \& Doré (1984) originally defined the Lomvi Formation and interpreted it to be of probable fluvial origin. The varied interpretations of the Lomvi Formation, fluvial (Vollset \& Doré, 1984; Steel, 1990), aeolian (Nystuen et. al., 1989) and nearshore/offshore (Lervik, 1983), suggest that there may bee too few data points to make firm conclusions on the depositional environment. However, the sand-rich and sheet-like character of the Lomvi Formation was used by Nystuen et al. (1989) to infer redeposition and winnowing by aeolian and fluvial processes. The same authors postulated that the Lomvi Formation was deposited during a period of low accommodation, caused by slow tectonic subsidence or insignificant changes in sea level. Steel \& Ryseth (1990) questioned the aeolian origin, as there is a distinct lack of diagnostic aeolian textures and lamination types. The pyrite in well NO 34/8-4S has not been described before. Both the presence of pyrite and the possibility that it is reworked may have implications for the interpretation of the Lomvi Formation. This is discussed further below.

\section{Alke Formation}

The Alke Formation defined by Lervik (2006) has a thickness of $299 \mathrm{~m}$ in its type well (NO 33/12-2) and $260 \mathrm{~m}$ in the reference well (GB 211/29-5). It comprises a thick, structureless, mudstone interval (up to $300 \mathrm{~m}$ thick) which forms a prominent sub-regional marker in the stratigraphy of the western part of the basin and can be used as a lithostratigraphic subdivision of the Triassic. The Alke Formation represents a sudden change to widespread mudstones, in contrast to the underlying sandstones of the Lomvi Formation (Fig. 5A, B). This abrupt change is striking and the pattern is somewhat analogous to similar major lithology changes in the Jurassic succession, i.e., from the Statfjord Group to the Dunlin Group, as well as from the Brent Group to the Viking Group (Fig. 6). The Alke Formation is succeeded by (and partly interfingers with laterally) the sandier Lunde Formation and a similar upward change to sandstones is observed in wells farther south (Sleipner Field area). Well NO 15/9-17, for example, shows a coarsening-upward pattern from relatively clean mudstone through mudstone and thin sandstones to the sandstone-dominated Skagerrak Formation.

The Alke Formation is defined by its generally monotonous and high gamma-ray log response. In well GB 211/13-1 the transition from the Lomvi Formation to the Alke Formation is sandstone to sandstone; this lower part of the succession (hereafter named the Alke sandstone unit within the Alke Formation) shows a fining-upward trend and the upper part shows a 'normal' Alke Formation pattern (well GB 211/13-1 of Fig. 5B). From west to east, between wells NO 33/12-5 and NO 34/10-13, there is a lateral change from massive mudstone to mainly sandstone, showing clearly that the Alke Formation interfingers laterally with the lowermost Lunde Formation. Wells in areas farther east also show sandstone facies of Lunde Formation that are coeval with Alke Formation, i.e., 34/7 and 34/8 wells (Fig. 5A, B). Although termed Alke Formation on the correlation panels, the westward pinch-out of sandstones shows clearly that the Alke and Lunde formations are coeval. The Alke sandstone unit was examined in cores from well NO 34/4-C-6H (Fig. 4B) where it can be subdivided into three intervals. The relatively fine grained interval below $3475 \mathrm{~m}$ is characterised by a mixture of dark grey sandstones and mudstones (Fig. 7A). The channellised fining-upward sandstones above $3475 \mathrm{~m}$ (Fig. 7B) are thicker and bioturbation varies from scarce to abundant. The channels contain large scale cross-bedding with prominent drapes, rip-up clasts, flaser lenticular bedding and wave ripple lamination. A few clasts of white coloured carbonate mudstone are observed. At 3452,60 $\mathrm{m}$ there occurs downcutting and infill of a different type of sedimentary facies, a coarser grained and sandier facies (Fig. 4B). Above $3436 \mathrm{~m}$ there are only a few mud drapes. The above occurrence of sandy channels illustrates well the likely lateral transition in places between the Alke Formation and the fluvial Lunde Formation.

There are synaeresis cracks within the Alke Formation (Fig. 4B) (Fig. 7C). Misinterpretation of synaeresis cracks as desiccation cracks can lead to errors in interpreting depositional environment. Buatois et al. (2008) showed good examples of synaeresis cracks. 

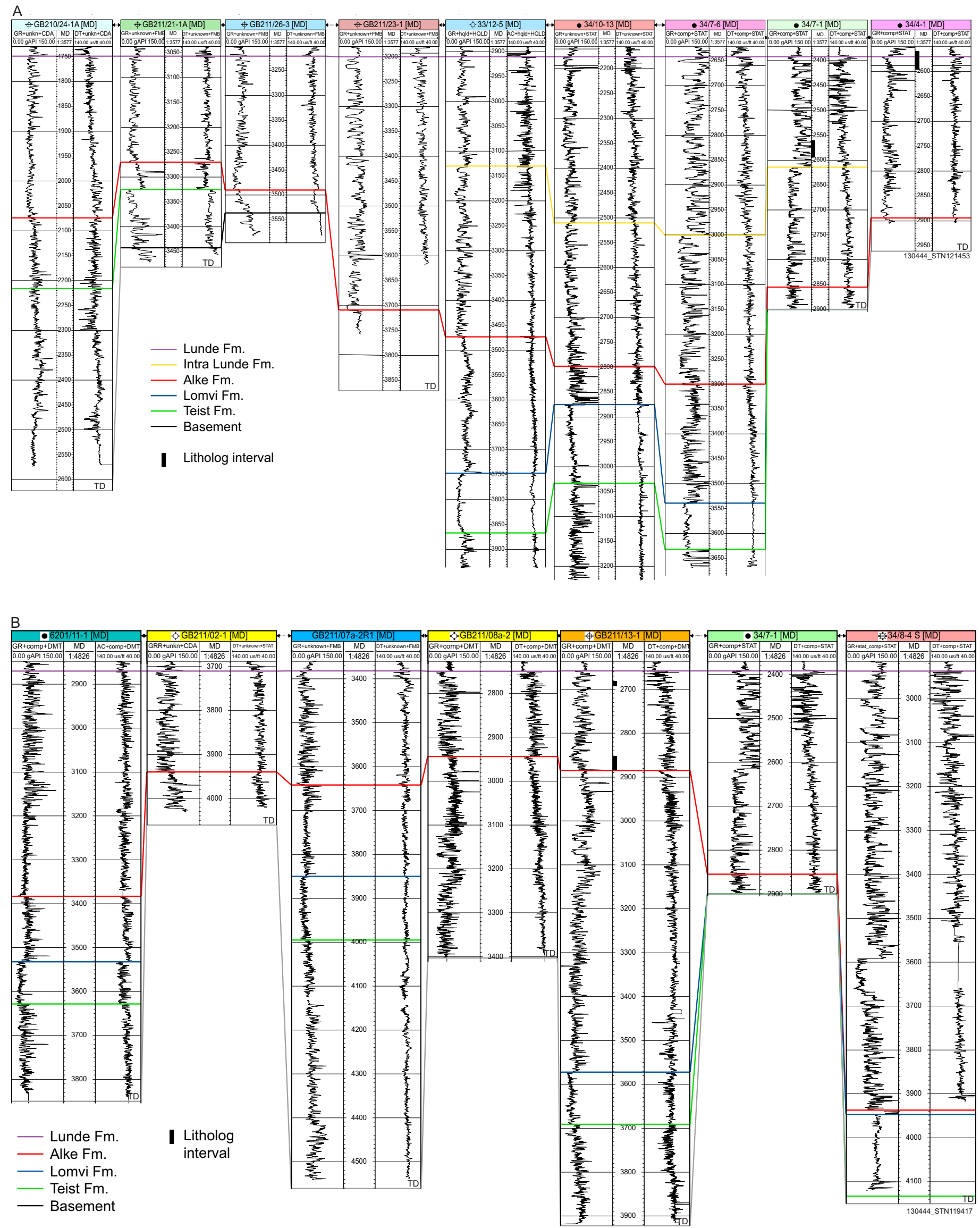

Figure 5. Correlations of the Triassic infill of the northernmost part of the northern North Sea. (A) West to east. (B) North to south. See Fig. 2A for locations. 


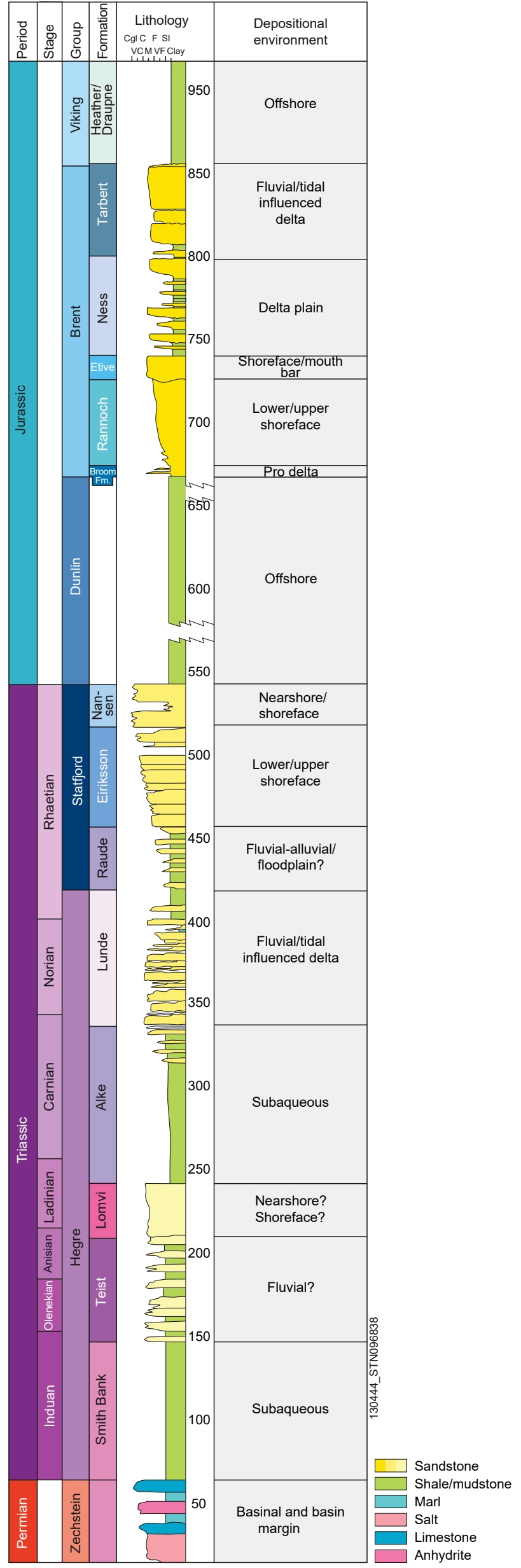

Figure 6. Permian, Triassic and Jurassic basin fill of the Northern North Sea Basin. 

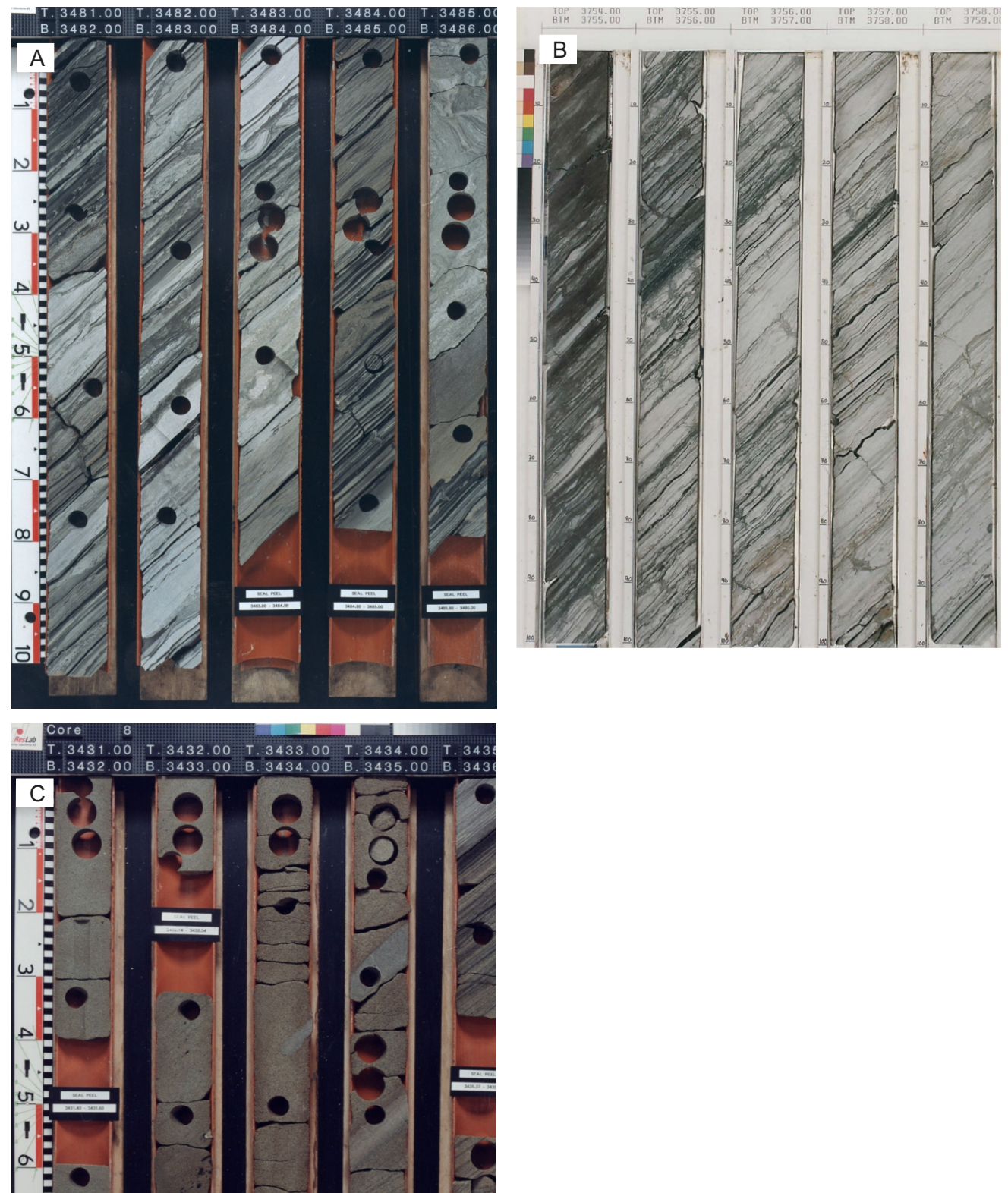

Figure 7. (A) Dark grey sandstones and mudstones from the fine-grained distal delta front of the Alke sandstone unit of well NO 34/4-C-6H (core photo of interval 3481-3486 m). The fining-upward sandstones above $3475 \mathrm{~m}$ are thicker, have an erosive base and bioturbation varies from scarce to heavy. (B) Example of delta plain facies of well NO 34/4-C$6 \mathrm{H}$ (core photo of interval 3431-3436 m). (C) Examples of water escape structures and/or synaeresis cracks (Depth 3754-3759 m of well NO 34/7a-2H).

Previous interpretation. Lervik (2006) defined and described the Alke Formation and interpreted the mudstones of the Alke Formation as a distal part of a prograding siliciclastic depositional system. In the Snorre Field area, the lower part of the Lunde Formation contains no prominent mudstone units and is deemed to be entirely sandy and fluvial. The lower part of the Lunde Formation in well GB 211/13-1 is similarly dominated by sandstone lithologies, representing a proximal environment relative to the more distal Alke Formation.

Revised interpretation. The thickness and relatively widespread distribution of the fine-grained Alke Formation strongly suggests that the mud accumulated in standing water, but was fed by more proximal, sandy river systems. The abrupt change to a finer grained lithology from the underlying Lomvi Formation, as well as the widespread occurrence of the Alke Formation, suggests that this boundary reflects a major base-level rise causing higher water-table and eventual lake levels. 

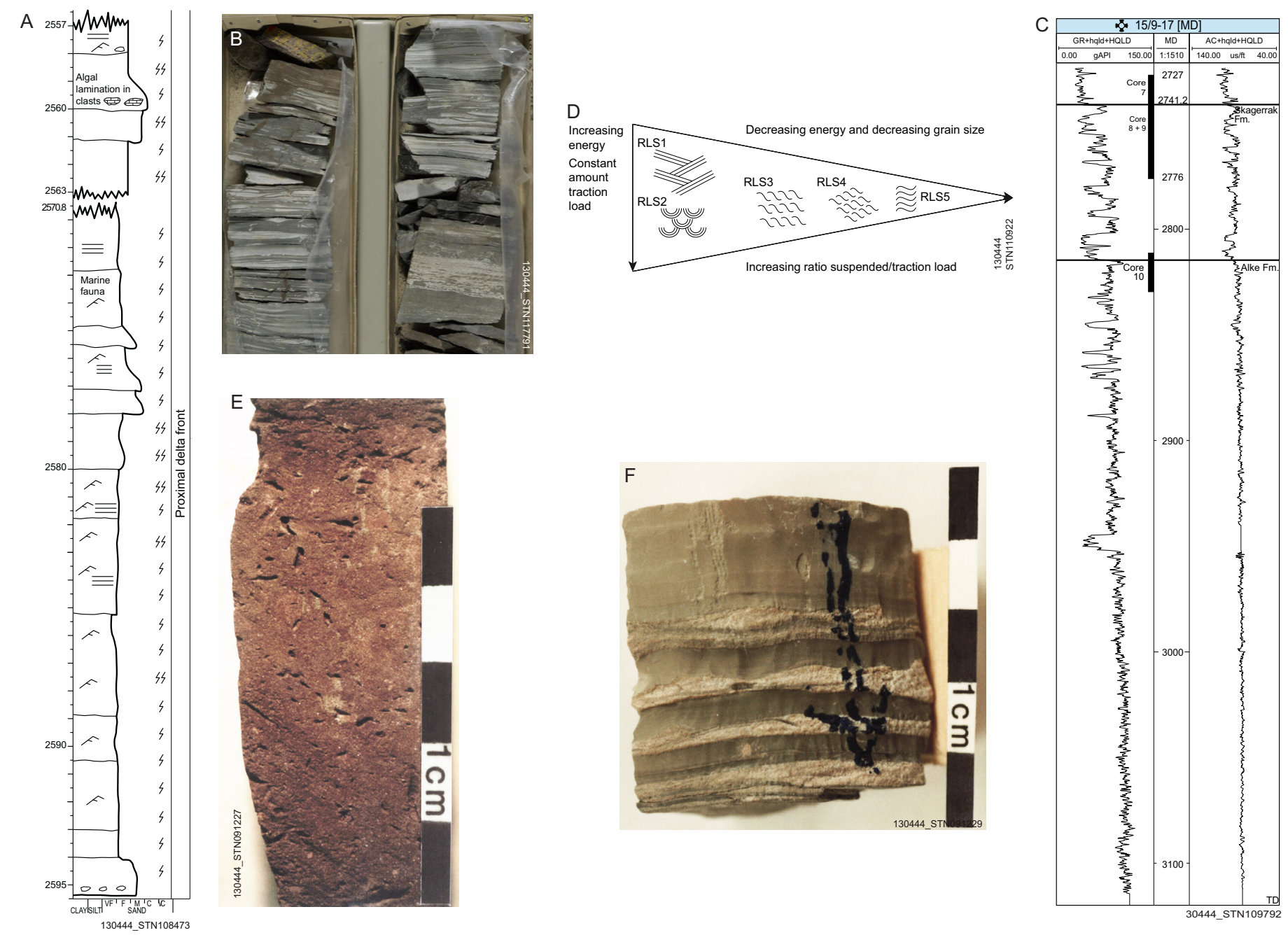

Figure 8. Strata from the Lunde and Skagerrak formations. (A) Litholog of interval 2557-2595.5 m of well NO 34/4-1 showing positions of clasts of finely laminated micritic limestone as well as marine fauna in a fluvial dominated succession of the Lunde Formation. Legend for litholog in Fig. 3. (B) Core photo showing heterolithic sediments interpreted as distal delta-front deposits (core 2 of well GB 3/24b-1a depth 3265.30-3267.15 m) (core width is $10 \mathrm{~cm}$ ). (C) Composite log of well NO 15/9-17 shows coarsening-upward pattern of the Alke and Skagerrak formations reflecting a prograding pattern of the depositional systems. (D) Interpretation of the ripple structures observed in well GB 211/13-1 (cores 1-4). (E) Dwelling structures of ants or insect larvae from a mudstone-dominated interval of well GB 211/13-1 (depth $2711.5 \mathrm{~m}$ (core 2)). (F) Laminae of micritic carbonate from the lower part of the Lunde Formation of well GB 211/13-1 (depth 2882.25 m (core 4)).

Wave ripples in the Alke Formation imply deposition in shallow standing-water environments. Clasts of carbonate mudstone (Fig. 8A) may be derived from stromatolites (lamination seen in core) and would also indicate standing water. Well GB 211/13-1 is located in a position where only the lower part of the succession was fed by sand from the east; the upper part shows that the sandy depositional system had retreated farther east. Wells in the NO $34 / 7$ and NO 34/8 areas are close to the proximal sand input and are dominated by very fine-grained sandstones through the entire Alke interval. The erosion/downcutting feature at $3452.6 \mathrm{~m}$ in well NO 34/4-C-6H (Fig. 4B) marks a possible nearshore or lake-plain facies of the deltaic system, prograding westwards to become the prodelta mudstones of the typical Alke Formation; the deposits around the boundary at $3452.6 \mathrm{~m}$ are interpreted either as shallow-lake or lake-plain deposits or as prograding delta-front deposits.

The cored interval of GB 3/24b-1a (Fig. 8B) shows upward-coarsening strata suggestive of distal delta-front deposits. Similarly, farther south, the deposits in well NO 15/9-17 are interpreted as the distal part of a prograding delta system - a transition from the subaqueous mudstone of the Alke Formation up to prodelta mudstone with sandstone layers whose tabular structureless character possibly suggests low-density delta-front turbidites. The succession coarsens upwards as the nearshore sandstones of the Skagerrak Formation overstep the pro-delta mudstones (Fig. 8C). 


\section{Lunde Formation}

The Lunde and Skagerrak formations, hundreds of metres thick, are the most penetrated and cored intervals of the Triassic succession. Two cored intervals of the Lunde Formation in well GB 211/13-1 are chosen to illustrate the facies (Table 2) and the varied depositional environments in the same well. The vertical difference in depositional facies likely indicates that lateral changes are also significant. Information on the cored intervals of wells NO 34/7-1, NO 34/4-1 and NO 34/8-4S have been included to support the interpretation of well GB 211/13-1.

Table 2. Facies of the Lunde Formation in well GB 211/13-1

\begin{tabular}{|c|c|c|c|}
\hline Code & Name & Description & Figures \\
\hline MS & $\begin{array}{l}\text { Massive } \\
\text { sandstone }\end{array}$ & $\begin{array}{l}\text { Fine to very fine sandstone. The lower interval of the massive } \\
\text { sandstone contains chips of green claystone. } \\
\text { FLS1: Undulating sand and clay laminae. The sand laminae are } \\
5 \mathrm{~mm} \text { to approximately two } \mathrm{cm} \text { thick while the clay laminae } \\
\text { average a couple of millimeters in thickness. }\end{array}$ & \\
\hline FLS & $\begin{array}{l}\text { Flat laminated } \\
\text { sandstone }\end{array}$ & $\begin{array}{l}\text { FLS2: Contains no separate laminae of clay. Planar laminae } \\
\text { within the sand define stratification, mostly less than five } \mathrm{cm} \\
\text { thick. Small amounts of silt or clay delineate the laminae. }\end{array}$ & \\
\hline RLS & $\begin{array}{l}\text { Ripple } \\
\text { laminated } \\
\text { sandstone }\end{array}$ & $\begin{array}{l}\text { The ripple laminated sandstone is classified into five subfacies: } \\
\text { ripple trough cross laminated sandstone; ripple planar cross } \\
\text { laminated sandstone; climbing-ripple cross laminated sand- } \\
\text { stone; ripple laminated/wavy bedded sandstone. The ripple } \\
\text { structures observed in cores } 1-4 \text { of well GB } 211 / 13-1 \text { are shown } \\
\text { schematically in Fig. 8D. }\end{array}$ & $8 D$ \\
\hline & & $\begin{array}{l}\text { Carbonate concretions and fragments of concretions, as in the } \\
\text { mudstone facies, are the main constituents of a } 25 \mathrm{~cm} \text { thick } \\
\text { green-grey conglomerate. It is clast supported and has a matrix }\end{array}$ & \\
\hline CGL & Conglomerate & $\begin{array}{l}\text { of mud and very fine sand grains mixed with material of the } \\
\text { same composition as the clasts. Most clasts are } 1-2 \mathrm{~mm} \text { in } \\
\text { diameter; the largest is } 3.8 \mathrm{~cm} \text {. Most of the clasts are spherical } \\
\text { or elongated. The elongate clasts show a preferential inclined } \\
\text { orientation relative to the core axis. }\end{array}$ & \\
\hline $\mathrm{M} \mathrm{s} / \mathrm{s}$ & $\begin{array}{l}\text { Massive sandy } \\
\text { siltstone }\end{array}$ & $\begin{array}{l}\text { The facies is a mixture of very fine sand and silt. At intervals } \\
\text { the sandy siltstone contains scattered, rounded, carbonate } \\
\text { concretions (few } \mathrm{mm} \text { to } \mathrm{cm} \text { thick). The siltstones are both red } \\
\text { and green. }\end{array}$ & \\
\hline & & $\begin{array}{l}\text { Silt and clay dominate the facies, which is both red and green. } \\
\text { Very fine grains of quartz, feldspar and mica are subordinate. }\end{array}$ & \\
\hline$M$ & Mudstone & $\begin{array}{l}\text { Some intervals contain concretions of carbonate }<1 \mathrm{~cm} \text { in size. } \\
\text { Parts of the mudstone are bioturbated. At depth } 2711.5 \mathrm{~m} \\
\text { (core } 2 \text { ) dwelling structures of ants or insect larvae are observed. }\end{array}$ & $8 \mathrm{E}$ \\
\hline C & Claystone & $\begin{array}{l}\text { The claystone is both red and green. It is interpreted to } \\
\text { represent suspension fall out during the latest stage of a flood } \\
\text { event. }\end{array}$ & \\
\hline MIC C & $\begin{array}{c}\text { Micritic } \\
\text { carbonate }\end{array}$ & $\begin{array}{l}\text { Separate layers of } 10-15 \mathrm{~cm} \text { thick, yellow-brown, micritic } \\
\text { carbonate are observed only in core } 4 \text {. Neither polarising } \\
\text { microscope nor SEM allow detection of any biogenic carbonate } \\
\text { remains in the micrite. }\end{array}$ & $8 \mathrm{~F}$ \\
\hline
\end{tabular}


The sandstone bodies are characterised by a fining-upward pattern, from relatively coarse-grained sandstone with reworked caliche nodules at the base, to cross-bedded sandstone grading upwards to rippled sandstones and a capping mudstone, commonly with calcareous nodules and root features.

Core 5 of well GB 211/26-1 shows a series of mass-flow deposits more than $7 \mathrm{~m}$ thick (Fig. 9A): white, coarse-grained sandstone with rip-up clasts of clay at the base (Fig. 9B) grade upwards to very finegrained sandstone (Fig. 9C) and finally mudstone at the top. Several similar but thinner units are present elsewhere in the cored interval.

Previous interpretation. Vollset \& Doré (1984) originally described the Lunde Formation as dominantly terrestrial, deposited in lacustrine and fluvial-plain environments. Lervik (2006) proposed that the Lunde Formation represented a major fluvial depositional system, building out from the Fennoscandian Shield, or/and from the East Shetland Platform. Nystuen et al. (2014) described the architectural styles of the Lunde Formation succession in the Snorre Field area and interpreted it as deposited in channel complexes of braided and meandering river systems.

Revised interpretation. The massive facies observed in the Lunde Formation in well GB 211/13-1 suggests a high sediment flux and a high rate of suspended load settling due to rapidly changing flow conditions. The flat lamination likely formed as part of river channel bars. The ripple laminated/ wavy bedded sandstone (subfacies RLS5) in Fig. 9D is interpreted to have been influenced by wave energy. The conglomerate formed by winnowing carbonate concretions from concretion-rich mud during reworking by fluid flow. The massive sandy siltstone represents passive settling of floodplain deposits connected to a channel system. Facies $\mathrm{M}$ is interpreted as similar to facies $\mathrm{M} \mathrm{s} / \mathrm{s}$ but, due to its finer grained composition, is a more distal deposit. Compared to the mudstone facies, the claystones represent sorting out into more distal parts of a depositional system. The micritic carbonate must have been biochemically or physico-chemically precipitated, most probably as algal mats reworked after precipitation.

On the basis of the frequency of transitions shown in the facies relationship diagrams in well GB 211/13-1 (Fig. 9E, F), two idealised facies sequences are outlined (Fig. 9G). Although vertical stacking, as in these generalised sequences is common, there are no examples of a complete succession of either sequence. The sediments of facies sequence I are interpreted as flash-flood deposits, related to desert rain-storm events (Lucchitta \& Suneson, 1981).

Idealised facies sequence I suggests localised mass-flow events formed subaerially during a flash flood. The mass flows resulted in beds one to three metres thick (Fig. 9H). Heavy rain can saturate sediment, thereby decreasing its shear strength. Decreased shear strength may lead to collapse and downslope movement of the sediment. Downslope movement of water precipitated during a heavy rainstorm will add a surface shear component to the system. The gravitational forces on rapidly moving water draining the slope may have triggered sediment gravity flows outside of the main river channels. For this type of sediment movement to occur, large amounts of precipitation are necessary on a subaerial slope. The waning currents at the distal end of an alluvial fan toe may produce a 'powering down' vertical sequence of poorly laminated gritty sand overlain by horizontally-laminated, medium sand capped by ripple cross-laminated, fine sand (Hardie, 1973). Such a sequence mimics the Bouma sequence and might be mistakenly attributed to waning turbidity currents in deep water (Hardie et al., 1978).

Idealised facies sequence II represents either the subaqueous part of a flash flow, which has turned into a true sediment gravity flow after reaching the basin water surface, or a subaqueous flow mechanism initiated by wave energy. The presence of the same facies succession in the lower part of facies sequence II, as in facies sequence I, suggests that the sequences are genetically related to each other. Upon reaching the water interface, the flow responsible for deposition of sequence I is thought 

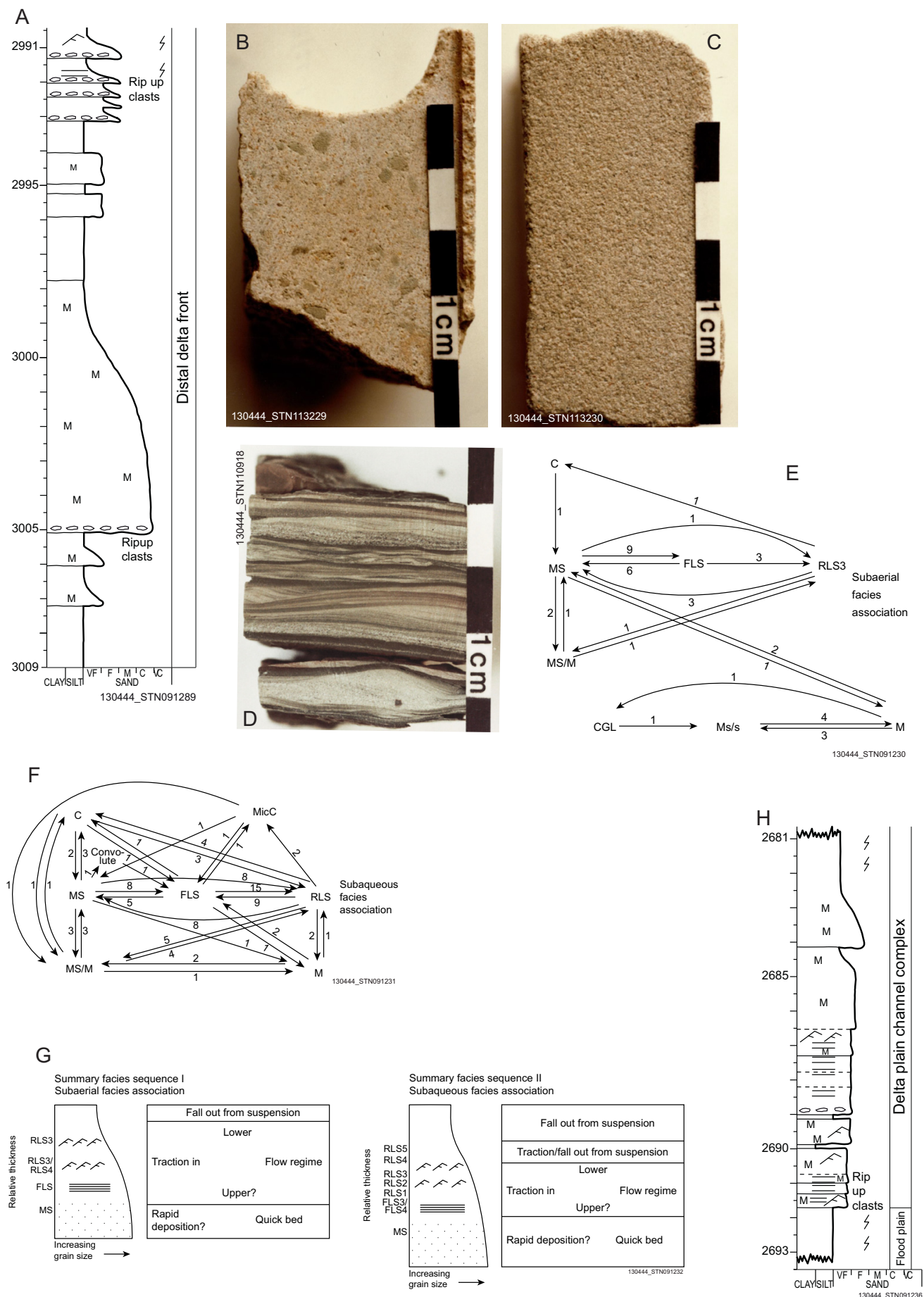

G
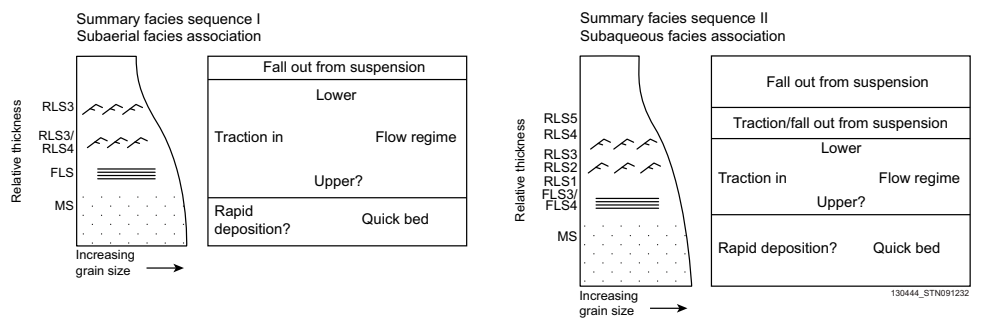

Figure 9. Strata from the Lunde Formation. (A) Litholog of interval 2900.50-3009 m (core 5) of well GB 211/26-1 shows a succession of mass-flow sequences intercalated with mudstone intervals. Legend for litholog in Fig. 3. (B) Lithology near the base of a mass-flow interval at depth $3005 \mathrm{~m}$ (core 5) of well GB 211/26-1. (C) Lithology of the upper part of a mass-flow interval at depth $3000 \mathrm{~m}$ (core 5) of well GB 211/26-1. (D) Ripples and wave-influenced strata of the lower part of the Lunde Formation of well GB 211/13-1. (depth $2872.5 \mathrm{~m}$ (core 4)). (E) Facies relationship diagram for the subaerial facies association of the Lunde Formation (cores 1 and 2 of well GB 211/13-1). Numbers indicate the observed number of facies transitions. (F) Facies relationship diagram for the subaqueous facies association of the Lunde Formation (cores 3 and 4 of well GB 211/13-1). Numbers indicate the observed number of facies transitions. (G) Summary facies sequences of the subaerial and subaqueous associations. (H) Litholog of interval 2681-2693 $m$ of well GB 211/13-1 (core 1). The mudstone at the base continues down with the same character another $23 \mathrm{~m}$ to depth 2715.5 m. Legend for litholog in Fig. 3. 
to have transformed into a true sediment gravity flow. On the basis of the facies succession, the lower part of sequence II (facies, MS, FLS, RLS1-4 with grain size fine to very fine) could be interpreted as deposition by turbidity currents. Bartolini et al. (1975) suggested that turbidity currents may have started as large river floods.

The presence of subfacies RLS5 makes it inappropriate to define facies sequence II as a typical turbidite sequence. Subfacies RLS5 is interpreted as deposited partly as fallout from suspension and partly under the influence of wave energy. Subfacies RLS5 may therefore have formed by wavegenerated currents related to the same storms as those responsible for the facies MS, FLS and the part of the rippled structured sandstones of traction origin. The position of subfacies RLS5 in the succession suggests that it represents deposition during the same event as the rest of the sequence rather than later reworking. Wave energy induced by storms may also be partly responsible for the initiation of a gravity flow responsible for facies sequence II.

From Fig. 9E it is clear that facies CGL, Ms/s and M represent a separate facies association. The presence of caliche nodules, which are reworked paleosols, combined with the fine-grained character of Ms/s and $M$, suggest that this facies association represents deposition in interdistributary areas supplied with fine-grained material transported laterally from the distributary. Facies CGL is a result of downslope transport of mud containing caliche nodules, with the caliche nodules winnowed out from the rest of the flow. The redistribution is thought to have been initiated by the same rainstorms as discussed for the facies sequences.

The micritic carbonate in cores 3 and 4 in well GB 211/13-1 indicates that sediments have been stirred up by storm energy and mixed together with clastic sediments from the marginal parts of a depositional system.

The sediments of the Lunde Formation in well GB 211/13-1 were supplied from a relatively distant hinterland of low relief reflecting their fine-grained nature. They are interpreted as deposited in a delta or fan-delta system, based on the dominance of flash flows and the evidence of both subaerial and subaqueous conditions, as well as distributary and inter-distributary associations. The presence of dwelling structures (Fig. 8E) made by ants or insect larvae proves that the upper part of the succession represents subaerial conditions. Micritic carbonate in core four suggests that the sediments of the lower part of the succession were laid down subaqueously.

Delta plain. The delta-plain facies is typically characterised by stacked fluvial channels in channel belts, as well as mud-dominated interchannel intervals, as discussed by Nystuen et al. (2014). Intervals of distributary channel sandy facies and intervals of interdistributary muddy facies in well GB 211/ 13-1 (Fig. 9H) suggest that channel complexes switched back and forth on the subaerial delta plain (Fig. 10A). The sudden change from mudstone facies to sandstone facies at $2691.7 \mathrm{~m}$ in this well typifies the dramatic character of the channel switching. The presence of low gamma-ray intervals - dominated by a sharp bottom and a sharp top - interbedded with intervals of high gamma-ray response, supports the concept of channel avulsions (Fig. 10A). Cored intervals of the Lunde Formation in well NO 34/7-1 (Snorre Field) confirm that the delta-plain environment lay east of well GB 211/13-1 (Fig. 10B).

The lack of typical distributary and interdistributary deposits within the subaqueous facies association suggests that the subaqueous part of the delta was dominated laterally by more uniform ('sheet like') deposition than the subaerial part.

Distal fluvio-deltaic. The facies association of the Lunde Formation in cores 3 and 4 of well GB 211/13-1 (Fig. 10C) is dominated by the upper parts of idealised sequence II, suggesting a more distal environment compared to the fluvial character seen in cores 1 and 2 . Synaeresis cracks in cores 3 and 

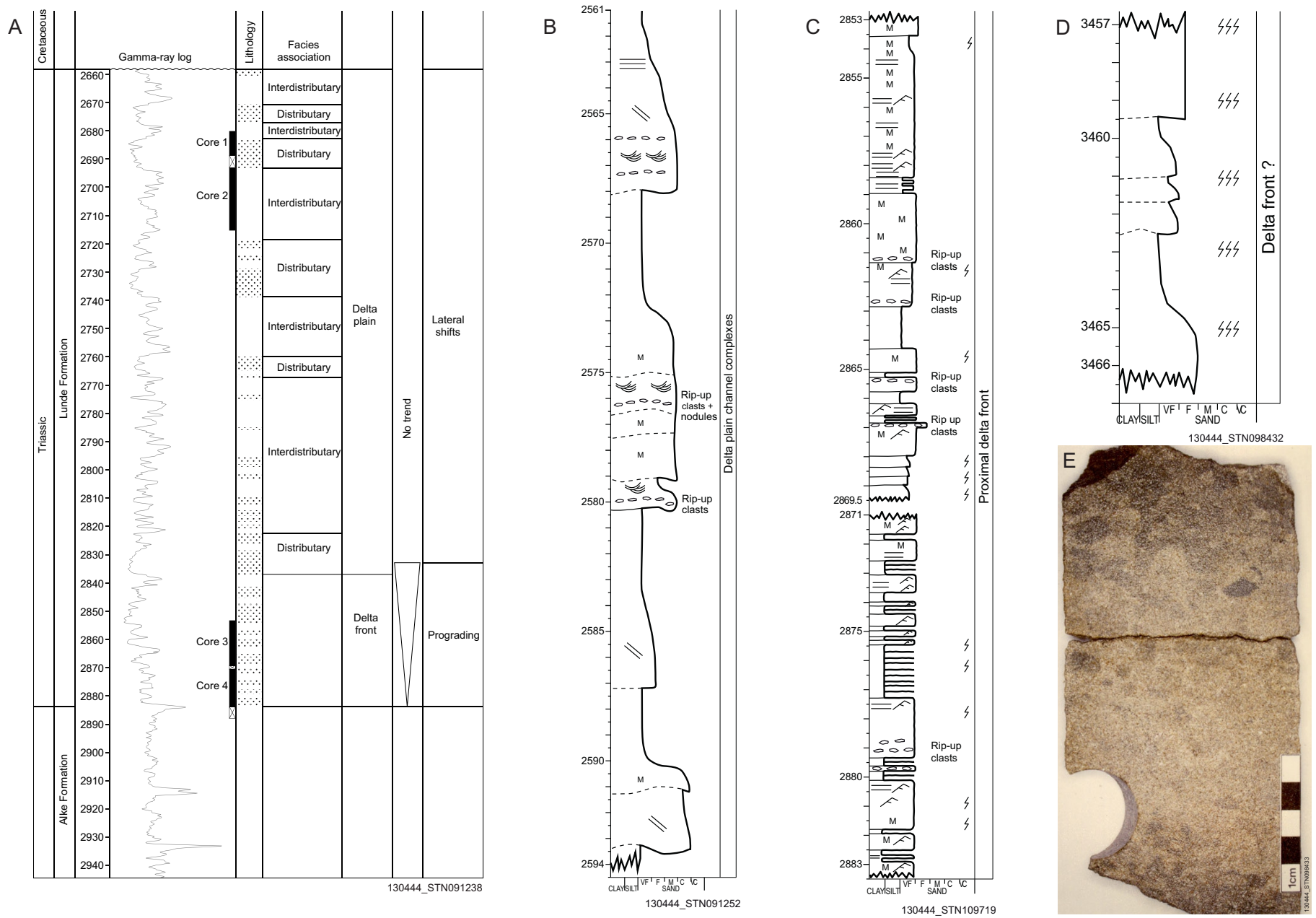

Figure 10. Strata from the Lunde Formation. (A) Interpretation of the Lunde Formation interval of well GB 211/13-1. (B) Litholog of interval 2561-2594 $m$ of well NO 34/7-1 showing delta-plain facies in the Snorre Field area. Legend for litholog in Fig. 3. (C) Litholog of interval 2853-2885.5 $\mathrm{m}$ (cores 3 and 4) of well GB 211/13-1 showing near-shore facies in the lowermost part of the Lunde Formation. Synaeresis cracks have been observed at 2872-2875 m. Legend for litholog in Fig. 3. (D) Litholog of interval 3457-3466.5 m of well GB 211/7a-2 shows fining-upwards units of bioturbated fine-grained sandstone. Legend for litholog in Fig. 3. (E) Example of bioturbated facies in well GB 211/7a-2 (3461.5 m).

4 imply the presence of standing water and probably formed due to salinity fluctuations. The overall coarsening-upward pattern from the mudstone interval of the Alke Formation below suggests that the strata of cores 3 and 4 of well GB 211/13-1 were deposited along the edge of a progradational alluvial wedge. There is a proximal-distal change of setting, from fluvial environments in the east to lowerenergy water-laid deposition in the west. This suggestion is based on observations of cored sections of the individual sub-environments from geographical areas in an east to west direction. Laminae of micritic carbonate at depth $2882.2 \mathrm{~m}$ suggests that coeval, carbonate algal mats were being eroded at some distance away from the site of the cored interval (Fig. 8F).

Subaqueous delta. The sediments of the cored interval in well GB 211/26-1 are interpreted as mass flows that were deposited subaqueously distally to the depositional system (Fig. 9A, B, C). Core seven of well GB 211/26-2 shows a similar pattern to well GB 211/26-1 and supports the interpretation. Further confirmation of a subaqueous type of environment in the western part of the basin is provided by wells GB 211/7A-2 and NO 6201/11-1. An example from the cored section of the Lunde Formation in well GB 211/7A-2 shows bioturbated sandstone (Fig. 10D, E), likely to have formed subaqueously. The $9 \mathrm{~m}$-thick core showing fining-upward motifs is totally bioturbated, with no remains of sedimentary structures. Bioturbation features have also been seen in the cored interval of the Lunde Formation of well NO 6201/11-1 (Fig. 4A) and can be subaqueous in origin. 
The proximal facies types of the Lunde Formation never reached the westernmost area. The flash floods which were initiated on the delta top continued under water and the $7 \mathrm{~m}$-thick mass-flow sequence of core 5 in well GB 211/26-1 is interpreted to represent the distal part of this type of flow. Wells from GB 211/23-1 and farther west show gamma-ray log patterns in the Lunde Formation which are typical of mass-flow sandstone bodies (Fig. 5A).

\section{Skagerrak Formation}

Deegan \& Scull (1977) originally defined the distribution of the Skagerrak Formation to be throughout the eastern part of the Central North Sea and the western Skagerrak. The partially coeval Lunde Formation has its distribution in the northernmost part of the northern North Sea (Vollset \& Doré, 1984, p. 14, table 2). Vollset \& Doré (1984) did not discuss the distribution of the Skagerrak Formation, but their table 4 (p. 16) showed the Skagerrak Formation to be present in the Norwegian-Danish Basin. Cameron (1993) and Lervik (2006) discussed the Skagerrak Formation as extending westwards into the UK sector. Fig. 1 of Lervik (2006) shows that there was a transition in depositional regime in Late Triassic time, from the evaporitic environments of the southern North Sea (Rhys, 1974) to the dominantly siliciclastic deposits in the northern North Sea. The sediments of wells GB 16/29-3X and NO 15/9-17 and also NO 15/9-14 are interpreted to represent the geographical area where the northerly siliciclastics transitioned into the basinal area with muddy floodbasins and areas of standing water. McKie (2014) discussed the Skagerrak Formation in the central North Sea area.

Few wells have drilled through the Triassic succession in the area between the Central Graben and the Norwegian mainland. Key well NO 17/12-1, which penetrated the entire Triassic succession, together with wells NO 10/8-1 and NO 17/10-1 are type and reference wells, respectively, for the Skagerrak Formation. No cores from this area are available, so the conglomerates, sandstones, siltstones and shale described by both Deegan \& Scull (1977) and Jakobsson et al. (1980) were interpreted based on well-log patterns and cuttings material. The mud logs of these wells show intervals of conglomerate, as well as an arkosic character of the sandstones, indicating a nearby source area. Except for the lowermost $100 \mathrm{~m}$ of the Smith Bank Formation, almost the entire $1700 \mathrm{~m}$-thick Triassic interval in well NO 17/12-1 consists of sandstones intercalated with some conglomerates and mudstones. Anhydrite, dolomite and limestone were also reported and were interpreted to imply marine incursions between floods of continental clastics (Jakobsson et. al., 1980). The depositional environments of these strata are not further discussed in this paper.

In the Central Graben area many wells have penetrated the Skagerrak Formation, but the Triassic is often truncated and overlain by Middle or Upper Jurassic sandstone-prone intervals of uncertain age. Therefore, in the absence of claystone intervals between the sandstone units, there might be an undated succession from Triassic to Upper Jurassic strata. This is the case in the greater Sleipner area where well correlations are difficult. Well NO 15/9-17 is assessed to have Skagerrak Formation strata below $2741.2 \mathrm{~m}$ (Fig. 8C), but this is truncated and overlain by Middle Jurassic strata, in turn succeeded by Cretaceous strata. This well is chosen as a key well with cored sections for the Skagerrak Formation, while wells NO 15/9-9 and NO 16/7-4 are used to support the discussion of the depositional environment of the Skagerrak Formation. In its overall gamma-ray log pattern, the succession is progradational as shown by its large-scale coarsening-upward pattern, from the mudstones of the Alke Formation through increasingly sandstone intervals, eventually reaching tens of metres in thickness and becoming the sandstone-dominant facies of the Skagerrak Formation. The interval $2776-2755 \mathrm{~m}$ (Fig. $11 \mathrm{~A}$ ) is dominated by mudstone, but with intercalated sandstone intervals from centimetres to one metre thick (Fig. 11B). At $2755 \mathrm{~m}$ there is a change from a mudstone-dominated lithology to sandstone-dominated lithology; this is the transition from the Alke Formation to the Skagerrak Formation. Below this transition rather thin-bedded, fine to medium- 
grained sandstones are dominant, with wave-rippled and flat-laminated sedimentary structures. Above this boundary, medium to coarse sandstones are dominated by trough cross-bedding as well as flat lamination and current ripple lamination. Rip-up clasts are common (Fig. 11C).

Previous interpretation. Most of the Skagerrak Formation was interpreted as a coalescing and prograding system of alluvial fans along the eastern and southern flanks of a structurally controlled basin (Deegan \& Scull (1977). The limited areal extent and poorly preserved faunal components of the Skagerrak Formation suggested that some of the dark shale, carbonate and anhydrite beds were deposited in distally or laterally sited lakes. Better preserved microfossils and other non-terrestial indicators such as glauconite were interpreted in terms of marine incursions that occurred between or lateral to progradational, dominantly alluvial, outgrowth phases.
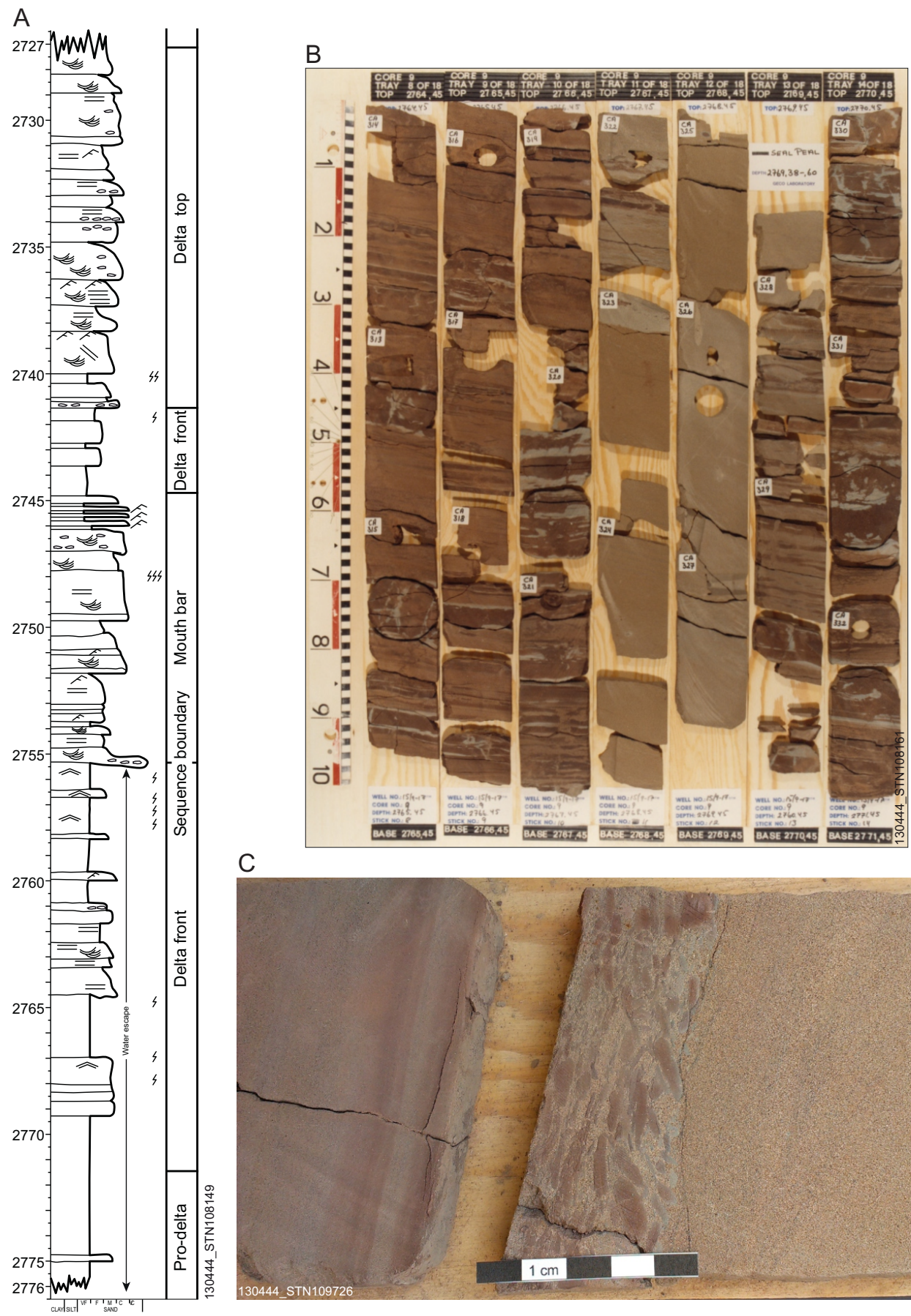

C

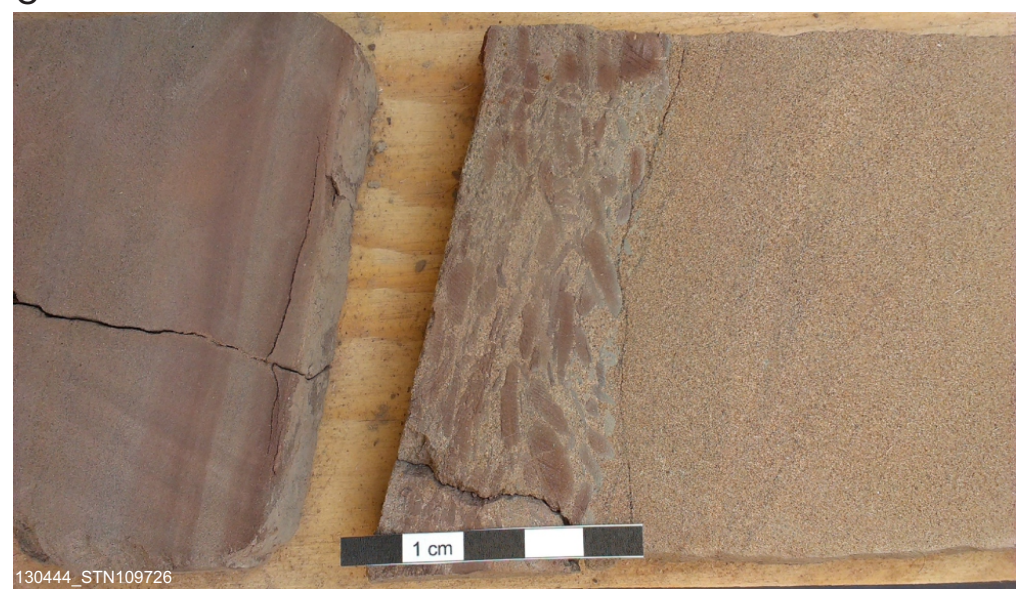


D

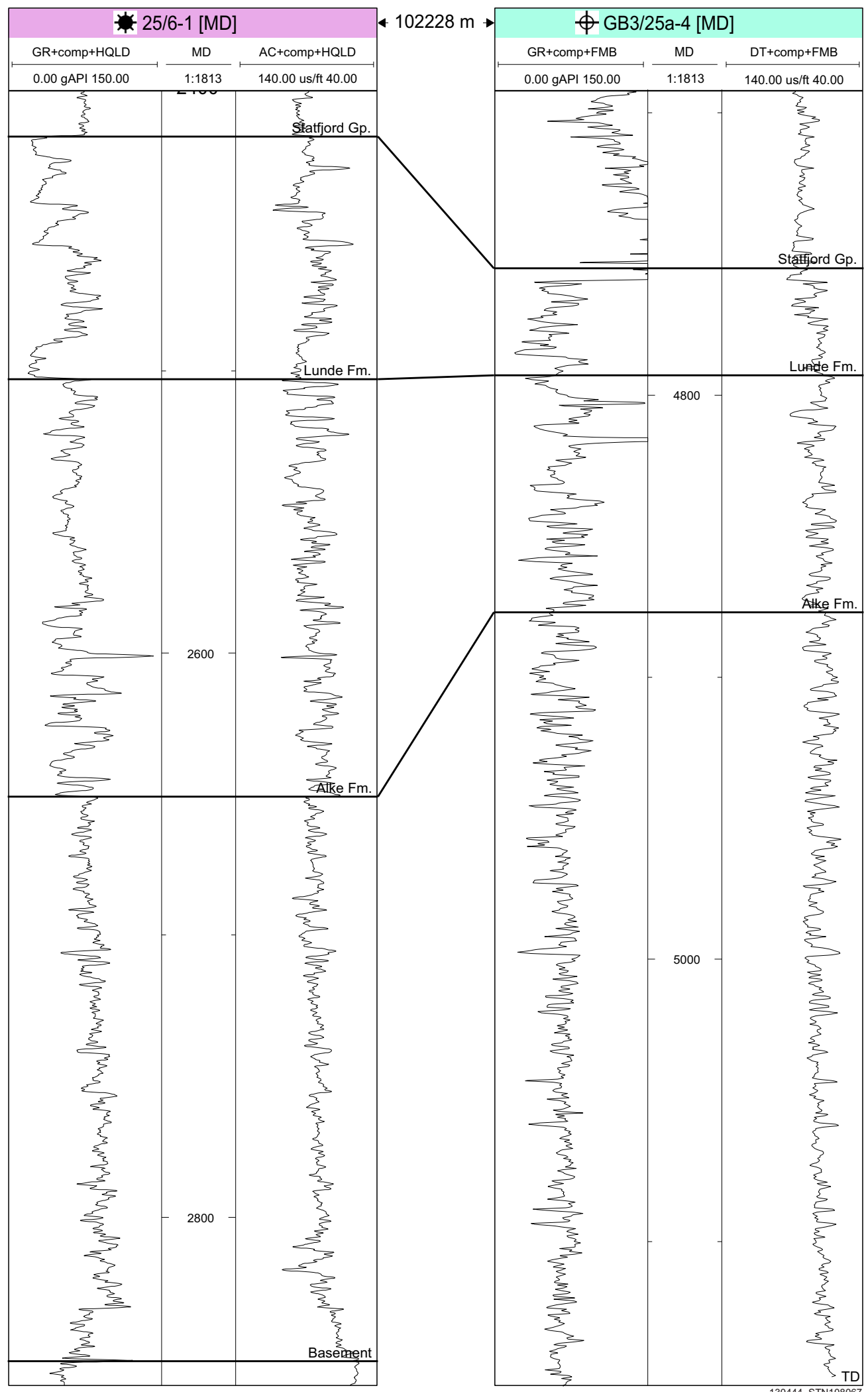

Figure 11. Strata from the Skagerrak Formation. (A) Litholog of interval 2727-2776 m of well NO 15/9-17 shows a prograding deltaic system from pro-delta mudstone to delta-top facies. (B) Example of the facies in the lower part of the prograding deltaic system of well NO 15/9-17 (2764.45-2771.45 m). (C) The boundary where delta-plain deposits of the Skagerrak Formation prograde delta-front facies of the Alke Formation of well NO 15/9-17 (2755 m). (D) Two wells to show the generally fine-grained sediments present between the Lunde and Skagerrak depositional wedges. 
Revised interpretation. The upward transition to sandstone benches above the muddier succession at $2755 \mathrm{~m}$ in well NO 15/9-17 is indicative of channel deposits and higher energy conditions compared to the deposits below. Some reworking by wave energy is indicated by wave ripples. The succession below the transition is interpreted to represent pro-delta and delta-front environments, while the succession above represents delta-front and mouth-bar environments. The interval 2755-2745 m (Fig. 11A) is interpreted as a mouth bar prograding over an earlier delta-front sequence.

The succession in core 10 (2811-2829 m) of well NO 15/9-17 (Fig. 8C) shows a typical precursor of the prograding delta, while cores 8 and $9(2741.2-2775.4 \mathrm{~m})$ represent the progradation of the delta system itself, building out on the prodelta mud of the Alke Formation.

Goldsmith et al. (1995) described the Skagerrak Formation in the southern part of the UK Central Graben (Quadrants UK 29, 30 and 39). Significant sandstone sedimentation began no later than the Anisian in this area suggesting that this location was in a distal part of the depositional system of the Skagerrak Formation.

The overall log pattern of the Skagerrak Formation probably reflects a very large-scale alluvial-deltaic system. It is difficult to distinguish Upper Triassic from Jurassic strata: it may be that both were deposited in similar depositional environments with the Jurassic eroding into the Triassic; they are compositionally similar.

In conclusion, regarding the Lunde and Skagerrak depositional systems, it is likely that they were dominated by semi-arid, ephemeral rivers and streams passing basinward into low-energy floodbasins and lacustrine areas that included some marine incursions. The depositional systems in the east were characterised by avulsing channel belts and associated muddier inter-channel areas; the large-scale alluvial prograding systems reached standing-water areas in places in the west.

\section{Triassic Basin Configuration and Sediment Infill}

\section{Triassic basin orientation}

The E-W basin configuration of the Northern Permian Basin of the central North Sea changed markedly to a N-S-oriented basin in Triassic time. Steel \& Ryseth (1990) suggested that rifting may have been initiated at least in Permian times, and their evidence from seismic data strongly suggested that rifting in the northern North Sea continued into Anisian-Ladinian times. It was further suggested that alluvial fans along the margins of the basin dispersed sandstones and mudstones into mud-and silt-dominated terminal floodbasins and lakes until the underlying rotated fault-block basins were 'drowned' during post-rift times.

Also Færseth (1996) reported that subsidence in the new basin configuration was greatest along the existing land mass of Norway in Early Triassic time. This N-S configuration, with a major sub-basin along the present-day west coast of Norway, resulted in major clastic input to the basin from the east. The depositional realm had therefore changed from evaporitic (Permian) to siliciclastic (Triassic).

However, the Triassic of the southern North Sea was still dominated by evaporite deposits, exemplified by well GB 49/21-2 (Haisborough Group, Rhys 1974). North of the Ringkøbing-Fyn High there is only limited evidence for similar thick evaporite deposits, as the basin had become dominated by siliciclastic infill. Large thicknesses of mudstone accumulated in the central parts of the basin as exemplified by 
well GB 15/26-1 (Lervik et.al., 1989, p. 180, fig. 8), whereas coarser clastic deposits dominated along the present Norwegian coast, as well as along parts of the western margin of the basin. A similar broad paleogeography was drawn by McKie \& Williams (2009) and McKie (2014).

\section{The problem of the environment distal to the river systems}

The widespread alluvial deposits of the Lunde Formation have been well documented (Nystuen \& Fält, 1995; Ryseth \& Ramm, 1996; Nystuen et al., 2014). However, the manner in which the channel complexes terminated into the basin has been little discussed. Several papers have discussed alluvial/ fluvial channel complexes probably ending in playa lakes - the most comprehensive is Mckie (2014) - but the sandy transitional parts of the playa lake deposits have not been extensively discussed. Playa lakes existed in Permian times when arid conditions prevailed and also in earliest Triassic times. By Middle and Late Triassic the progradational alluvial systems appear to have built into standing bodies of water, as evidenced by the characteristic upward-coarsening successions described above, as well as the change to a more humid climate through the Triassic, as discussed by Nystuen et al. (2014). Major distributary channel complexes reached into standing bodies of water, where the depth of the water body must have been at least some few tens of metres (reference is made to mass flow of $G B$ $211 / 26-1$, Fig. 9A-C). This is in contrast to the arid to hyper-arid environment described by Lang et al. (2004).

The distribution of the Triassic formations was described in Lervik (2006), where two regional well correlations show the development of the Triassic succession in relation to basin fill (Fig. 5A, B). Fig. $5 \mathrm{~A}$ suggests that after the accumulation of the Lomvi Formation, the centre of the basin was close to the location of well NO 33/12-5, where the Alke Formation is thickly developed, reflecting uniform mudstone deposition across the distal part of the depositional systems. The wells to the east of NO 33/12-5 show a thin interval of Alke Formation overlain by a sandstone-prone interval representing both the Alke sandstone unit and the Lunde Formation. In a westward direction the wells GB 3/18c-1, GB 3/19b-2, GB 3/24c-4 and GB 3/24b-1A all show mainly fine-grained sediments of the Alke Formation resting directly on basement: the subsidence was late and the area was a source for sediments until Alke Formation time. To the east, however, the full succession of the Triassic is present (Lervik et. al., 1989), suggesting that this part of the basin was filled by sediments from the east. Farther north, wells NO 6201/11-1, GB 211/2-1 and GB 211/07a-2 show continuous basin filling during the entire Triassic. As the 33/12-area was the centre of the basin (thickest mudstone intervals of the Alke Formation), it is natural to infer that there was input of sediment from both east and west.

\section{Provenance of the Triassic sediments}

In the overall setting of a $\mathrm{N}-\mathrm{S}$ elongated basin, with the Norwegian Caledonides to the east but more diverse structural elements to the west, it is likely that the major part of the sediment fill originated from the east, with smaller input from the west. Several authors have discussed the sources of the sediments of the Triassic reservoirs in the northern North Sea (Mearns et al., 1989; Steel \& Ryseth, 1990; Ryseth, 2001; McKie \& Williams, 2009; Archer et al., 2010; McKie et al., 2012). Mearns (1989) concluded that the provenance ages for the (upper) Lunde Formation are not diagnostic of any specific source area but are compatible with either easterly (Norwegian), westerly (Shetland Platform) or southwesterly (Scottish mainland) sources.

In the northernmost North Sea, east-west well correlation shows a clear transition from a thick mudstone succession of Alke Formation in well NO 33/12-2 to intercalated sandstones-mudstones within the Alke Formation in well NO 34/7-6. The thick mudstone interval of the Alke Formation 
continues to be present farther west, but in the eastern part of the basin there are no major mudstone intervals post-Lomvi Formation time. The replacement of mudstone with sandstone in an easterly direction is a clear documentation of a prograding clastic wedge, the Lunde clastic wedge, sourced from the east and transported into a standing body of water in the west. In the far east there is a continuous Teist-Lunde succession of sandstones and some mudstones, but Lomvi and Alke formations are not present in the eastern part of the basin. An earlier suggestion that Alke and Lomvi formations are present in the Horda Platform wells (Lervik, 2006, p. 106 and p. 108, figs. 9 and 10) is now believed to be mistaken: revision of the Triassic succession across the region has shown that the Lomvi and Alke formations are not present in those wells.

\section{Norwegian Caledonide sourcing}

The main source for the northern North Sea Triassic sediments was the Caledonian Norwegian mainland, partly via a valley along Sognefjord, eroded from the mountain upland area. Standing water in the west was present during the deposition of the carbonate and anhydrite lithologies in Permian time. Wells GB 210/4-1 (Lervik et al. 1989), GB 211/11b-4 and GB 220/26-2 are locations where Zechstein facies are present, and suggest that the area was an area of low relief in the Triassic. There were no major positive structural elements to the north or south, so a N-S axial sediment transport direction is less likely. Valleys pre-dating the modern fjords of West Norway were the most likely sediment supply routes in Late Triassic times. There are not enough well data points to give a clear picture of the basin configuration in the west of the northernmost northern North Sea, but the Alke Formation resting directly on basement in well GB 211/26-3 and a short Teist Formation interval in GB 211/21-1A show that erosion of those areas continued until at least Middle Triassic time. A thick sequence of Triassic strata in the Unst Basin (well GB 210/24-1A) suggests that this area may have trapped sediments from the west, perhaps restricting input of sediments to fill up the main basin farther east. The major part of the Triassic depositional system in the northernmost part of the basin was sourced from the east.

Correlation of the Lunde wedge southwards shows that it becomes dominated by finer-grained sediments, here exemplified by wells GB 3/25a-4 and NO 25/6-1 (Fig. 11D). Farther south another wedge, the Skagerrak clastic wedge, built out coevally with the Lunde wedge (Fig. 12C). Frostick et al. (1992) discussed the Lomvi Formation in well NO 25/4-1. The GR log pattern looks similar to the Lomvi Formation, but according to the lithology reported on the completion log (mud-log) there is shale through the entire interval. The shale is reported to be black-grey as well as red-brown. Just below the base of the Lomvi Formation there are rare small shell fragments reported on the completion log. The fine-grained lithology of the Triassic interval of this well shows that this area was far away from the main focus area of sediment input to the basin. Ryseth (2001) observed that the lithologies of the Statfjord Group on the Utsira High are finer grained and the associated flood-plain deposits contain higher proportions of non-pedogenic deposits than lithologies from the Tampen Spur and Horda Platform. This observation led to the conclusion that relatively high depositional gradients existed on the Tampen Spur to the north, whereas there were relatively low gradients on the Utsira High to the south. This gave rise to the conclusion of a southerly drainage direction for the Statfjord Group, which was also suggested for the older Triassic alluvial system. Ryseth (2001) concluded that stratigraphic relationships were indicative of a south-directed Triassic fluvial drainage system in the Viking Graben. From north to south, from the Tampen Spur to the Utsira High, wells show that the lithologies become fine grained. However, south of the Utsira High, coarse clastics of the Skagerrak Formation prevail (Skagerrak wedge). 

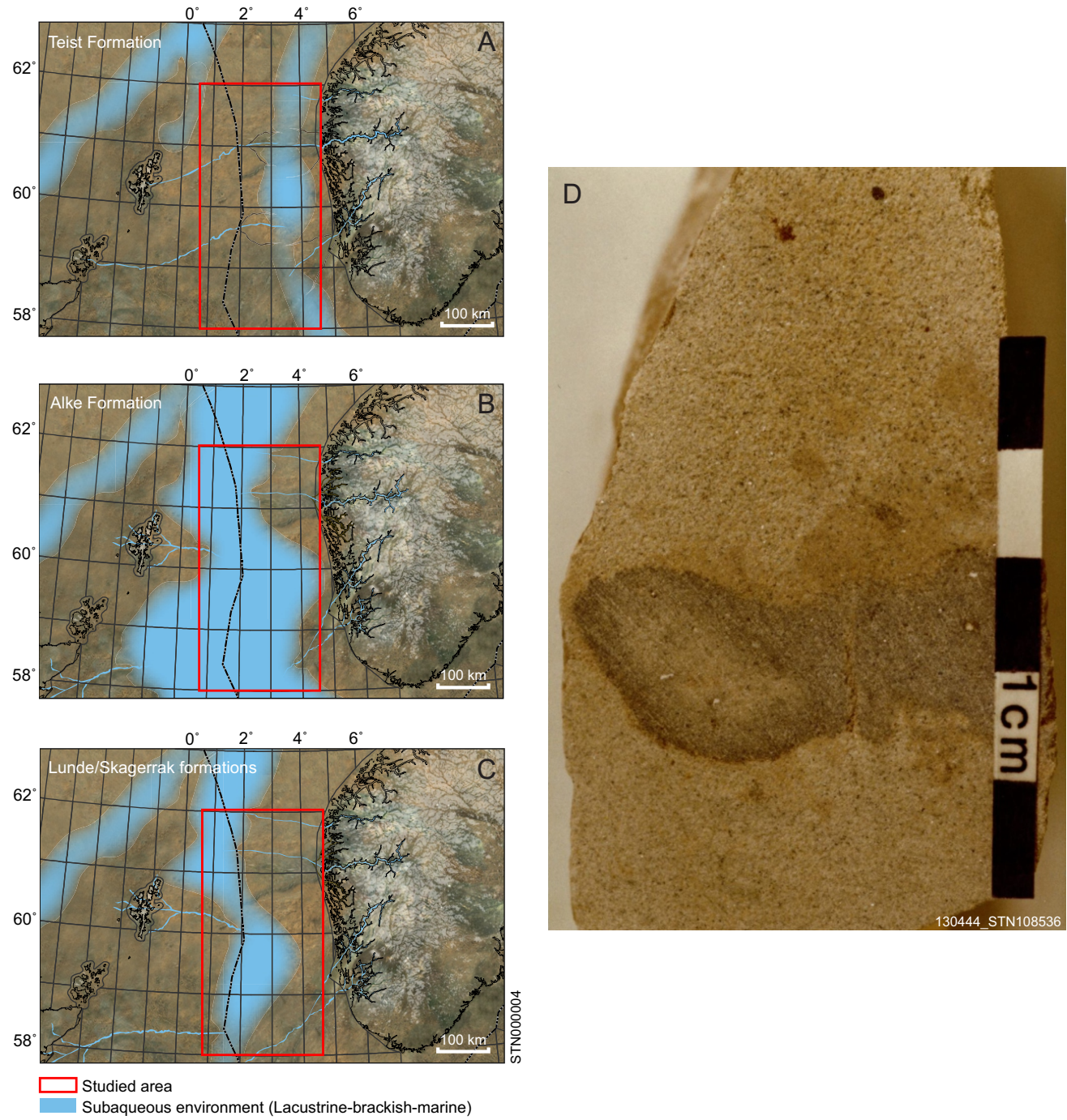

Figure 12. (A-C) Palaeoenvironmental maps of the Teist, Alke and Skagerrak/Lunde formations of the Northern North Sea Basin. (D) Re-distributed pyrite in sandstone of the Lunde Formation at depth $2854.35 \mathrm{~m}$ (core 3) of well GB 211/13-1.

\section{Evidence from the western side of the basin}

Archer et al. (2010) and McKie et al. (2012) discussed Triassic infill of the Northern North Sea Basin, implying infill of sediments from both the east (Norwegian Caledonides) and the west (Scottish Highlands). Palaeocurrent data from the Heron Field in the Central North Sea (Fig. 1) showed a dominance of flow towards the southwest and to the south-southeast within the upper Skagerrak section. This southerly, axial transport direction of the upper Skagerrak section suggests that the basin was being filled in the north, with excess sediments shed in a southerly direction where accommodation space was still available. McKie \& Williams (2009) measured outcrops on the south coast of the Moray Firth, suggesting palaeo-flow to the east. Frostick et al. (1992) discussed Triassic sediments in the Beryl Embayment and described sediment transport in a westerly direction: this was a local basin with internal drainage. Goldsmith et al. (2003) discussed the extensive infill of the Moray Firth Basin, where sediments were most probably directed eastwards towards the central part of the main basin and into the Viking Graben or Central North Sea. Depositional systems radiated from the Hardanger-Boknfjord system, as well as from the Moray Firth system, and when the accommodation space was filled up in the meeting point area the depositional systems may have turned southwards towards the southern North Sea where accomodation space was still available. 
Several authors have concluded that the basin configuration and sediment input in the Triassic of the northern North Sea were such that clastic materials came from the hinterlands both in the east and in the west (Steel \& Ryseth, 1990; Nystuen \& Fält, 1995; Morad et al., 1998; Goldsmith et al., 2003; McKie, 2014). It is here proposed, instead, that the major fluvial sediment transport and discharge was towards the west from a hinterland in the east into a roughly $\mathrm{N}-\mathrm{S}$ elongated basin/alluvial plain. Fig. 9.1 of Goldsmith et al. (2003) suggested that there was not enough exposed land mass in the west to supply substantial amounts of sediment to the western part of the northernmost northern North Sea.

\section{The Lomvi problem}

Steel (1990) discussed whether slow rates of base level rise, or even uplift-generated base level fall, were major factors in reworking and amalgamation of the fluvial channel belts of the Lomvi Formation, as well as the high rate of progradation into the basin. This should be accompanied by the input of coarse clastics along the eastern margin of the basin, but the cored sections of the Lomvi Formation show that grain size is fine to very fine, and there are no coarse clastics in the successions of the studied wells lying closer to the eastern basin margin. In wells close to the eastern margin the Lomvi Formation is not present. Frostick et al. (1992) described the Lomvi Formation from the Beryl Embayment and explained the sudden change in sediment character that took place at the onset of Lomvi times in the Beryl Basin as due to a shift in climate and vegetation, with a higher rainfall/runoff ratio. The lower massive part of the Lomvi Formation was interpreted as having been deposited as a result of drainage from hanging-wall regions and the upper, more irregular pattern, as a result of prograding drainage into an ephemeral lake.

Herein the Lomvi Formation is interpreted using the stratigraphic context of the depositional units below and above. The transition to massive sandstones from below and the sudden change to mudstones above witness changes in the positions of facies belts. The mechanism of these pattern changes is discussed in a broader context below.

\section{Lunde and Skagerrak formations -- depositional pattern}

Triassic accommodation space became filled in proximal eastern areas during the early Triassic period so that Upper Triassic systems prograded westwards into the more central parts of the basin. The depositional system of the Lunde Formation was supplied by sediment from the present Sognefjord area (Fig.12C), anticipating Jurassic depositional systems. The depositional wedge of the Lunde Formation is interpreted to have been a precursor to the depositional wedge of the Late Jurassic Sognefjord Formation (Nøttvedt \& Johannessen, 2013).

The East Shetland Platform was exposed during the Late Triassic (Lunde Formation), supplying sediments from the west into the basin. The central part of the northern North Sea was sheltered from sediment input from the north and northeast by the Utsira High; it was supplied with sediments from a depositional system off the East Shetland Platform. Frostick et al. (1992) discussed the Triassic infill of the Beryl Basin, amounting to in excess of $1000 \mathrm{~m}$ of sediment since early Triassic time.

The Skagerrak wedge likely had its sediment supply emerging from the present-day Hardangerfjord area, associated with the Hardangerfjord Shear Zone. There was also a major sediment supply contribution from the Boknfjord area, a fjord area south of Hardangerfjord. The absence of both 
the Alke and the Smith Bank formations within the succession in the most proximal parts of the Skagerrak system indicates that an alluvial setting prevailed here in the east during Middle and Late Triassic, similar to the situation for the Lunde Formation (Lervik, 2006). Similarly, a wedge of the Skagerrak Formation built out from the Moray Firth Basin.

The area between the major depositional systems building out from the east during the Triassic may have been a mega-embayment, with the major part of the sand channellised via the two major river routes discussed above, and the area between the clastic wedges dominated by finer-grained sediments and minor sand input. Sediments shed westward from the two major input areas were deposited in alluvial/fluvial environments in the east and in a subaqueous environment to the west. In the far west, sediments were redistributed within subaqueous environments. The character of this standing body of water to the west is uncertain; the lack of marine fauna suggests it was a small and restricted offshore basin area dominated by a high influx of freshwater; a fresh rather than hypersaline water type fits with the semi-arid or even wetter climate during the Late Triassic.

The overall fining-upward pattern of the Lunde Formation of the northern North Sea implies that the basin was being infilled, and quiet tectonic conditions prevailed at the end of the Triassic. The onset of deposition of the Statfjord Group reflects renewed sediment supply and perhaps a new tectonic pulse, which caused further subsidence and the introduction of coarser sediments on top of the finegrained upper part of the Lunde and Raude formations. Subaerial depositional conditions are suggested for parts of the fine-grained units of the Statfjord Group by the presence of calcrete, coals and roottraces. In contrast, delicate lenticular and flaser lamination, wave-ripple laminae and abundant bioturbation suggest that the other parts of the fine-grained units were deposited in standing water (Røe \& Steel, 1985). Based on the stacking pattern of facies associations and the presence of marine fossils, they interpreted the uppermost Nansen Formation to have been deposited in a marine environment. The Statfjord Group had a similar provenance and comparable depositional setting as the Lunde Formation, except that the Statfjord Group contains coal in the Eiriksson and Nansen formations reflecting a more humid climate than the Lunde Formation. The Gassum Formation in the Norwegian-Danish Basin has been described as deposited in a foreshore/shoreface depositional environment with tidal energy (Nielsen, 2003). The depositional setting of the Statfjord Group may have been similar to that in the Norwegian-Danish Basin; the marine influence interpreted by Røe \& Steel (1985) for the Nansen Formation may have been from an extension of the marine waters in the Danish sector as suggested by Ryseth (2001).

In summary, a conceptual paleoenvironmental map is presented in Fig. 12A to demonstrate how the Teist Formation may have been deposited. The map is based solely on the conclusion that ephemeral fluvial systems drained into the deepest part of the basin which at that time was in the east (Færseth 1996).

The depositional patterns of the Lomvi, Alke and Lunde formations are thought to have been controlled by external drivers such as tectonics (influencing both sediment supply and subsidence) and climate, in addition to autogenics within the depositional systems. Sedimentary facies patterns show that the major depositional systems developed from east to west, proximal to distal. The dramatic change from the featureless sandstones of the Lomvi Formation to the muddy Alke Formation is interpreted as representing a basinwide adjustment of rising base level, probably due to an increased rate of subsidence. The depositional systems were pushed landward and the sediments of the Lomvi Formation were flooded by the muddy basin water. After this depositional adjustment, the depositional systems again rebuilt as reflected by the progradation of the Lunde Formation clastic wedge from the east and the Skagerrak clastic wedges from east and west. The thick, subaqueous, mass-flow deposit observed in well GB 211/26-1 suggests that the water depth must have been at least some tens of metres. This pattern is interpreted to have been basinwide. The basin water type is discussed below. 
Palaeoenvironmental maps of the Alke Formation and the Lunde and Skagerrak systems are presented in Fig. 12B, C.

\section{Discussion}

\section{Did standing bodies of water exist in Triassic time?}

This article has proposed that parts of some of the Triassic formations (Smith Bank, Alke) were deposited in standing bodies of water in the distal reaches of extensive, progradational depositional systems. However, the evidence for the standing bodies of water is either sparse (rare fossils) or tentative (facies analysis from cores). The Smith Bank Formation succeeds the Zechstein Group which is marine in origin and thereby provides circumstantial evidence that marine waters potentially flooded the earliest Triassic syn-rift depocentres. The strongest evidence for standing water in the Triassic is provided by Eide (1989) who found the acritarch Schizocystia sp. in the Alke Formation (middle Lunde unit) in ten different wells over a relatively wide area in the Snorre Field. The good preservation of the fossils was interpreted to reflect subaqueous deposition, supporting the idea that a water body covered most of the Snorre area during the Norian to Early Rhaetian interval. Thin layers of micritic carbonate in core 4 of the Lunde Formation in well GB 211/13-1 (Fig. 8F) are interpreted to have been internally reworked from physico-chemical precipitates or algal mats. Such micritic carbonate suggests that the sediments of core 4 in GB 211/13-1 were also deposited in water. Wave ripples from the same core (Fig. 9D) also indicate at least a very shallow standing body of water. Clasts of finely laminated micritic limestone, in which the laminations appear to be algal in origin, occur also in the Lunde Formation at 2559,75 m in well NO 34/4-1 (Fig. 8A). In situ horizons of calcite fragments are present at certain levels, particularly at $2573,75 \mathrm{~m}$. This coincides with recorded levels of marine microfauna. According to the well operator (completion report), the presence of a very weak marine influence is indicated by the ocurrence of single specimens of Tytthodiseus? faveolus (2545.7 m), Cymatiosphaera sp. (2547.7 m) and Tasmanites sp. (2578.7 m).

The facies analyses and interpretation of core data presented here suggest that the Triassic infill of the northern North Sea formed as major progradational and backstepping depositional systems. Those systems terminated into muddy standing water, sometimes perhaps simply as large alluvial floodbasins, but at other times as lacustrine and brackish-water areas as evidenced by the type of facies seen in cores, e.g. the mass-flow sequence of more than $7 \mathrm{~m}$ (Fig. 9A-C) of well GB 211/26-1 (Lunde Formation). It is therefore concluded that the central part of the basin contained standing water with sediment infill from the eastern and northwestern margins.

\section{Were the standing bodies of water lacustrine or marine?}

The lack of marine biota through the entire Triassic succession excludes the possibility that the basin water was permanently marine. Nor are there biota of lacustrine origin. The best evidence of marine incursions is from the Alke Formation of the Snorre Field, in the northwestern areas. There, Eide (1989) suggested lacustrine or marginal marine environments for the Alke Formation (middle member of the Lunde Formation), as evidenced by the presence of the acritarch Schizocystia sp.. There are several related observations. Can the GR-peak at $3540 \mathrm{~m}$ in well NO 33/12-5 represent a maximum flooding event and reflect a high relative sea level of Early Norian times? It should be stressed, though, that dating is speculative. Also, an approximately ten metre-thick interval with high GR readings (combined with characteristic low neutron readings) occurs in the uppermost part of the mudstone interval of the Alke Formation/Alke sandstone unit below $3300 \mathrm{~m}$ in well NO 34/7-6 (Fig. 5A) and can be 
correlated throughout the Snorre Field area (M. Bergan, pers.comm., 2018). This interval is interpreted to represent the same marine incursion (maximum flooding event) as discussed above. Lastly, Stanley et al. (1990) described a mudstone interval in the uppermost strata of the Lunde Formation in the Snorre Field and interpreted it to represent an event of maximum marine flooding in the Tampen Spur area. This interval of mudstone is also observed in other areas (i.e., NO 30/6-1; NO 33/5-2; GB 211/13-2) confirming it was a semi-regional event.

\section{Standing bodies of water: evidence from areas to the north and south.}

Bugge et al. (2002) reported a fully marine succession of Late Permian-Early Triassic age on the eastern margin of the mid-Norwegian shelf. This was part of the marine depositional basin between Greenland and Norway (Seidler et al., 2004). Permian strata in the northernmost North Sea (well GB 210/4-1 in Lervik et al., 1989, p. 182, fig. 10 and well GB 211/11b-4) would have been part of the same depositional regime as the Permian strata of the mid-Norwegian shelf, prior to opening of the Møre Basin. Wiik-Jacobsen \& van Veen (1984) discussed a subsidence phase when the Griesbachian sea transgressed into the northern North Atlantic Rift Basin. There is a more accurate timing of this tectonic event in East Greenland based on ammonoid data and radiometric dating (Early and Late Griesbachian) (Seidler et al., 2004), suggesting that middle Early Triassic time was when the major basin forming activity took place.

Clemmensen $(1978,1980)$ reported a marine transgression which brought sandy calcarenites and limestones with a boreal fauna to the East Greenland area in Middle Triassic times. Andrews et al. (2014) re-dated part of these strata as Mid-Carnian and reported evidence for periodic marine flooding - the southernmost evidence of the Boreal Ocean during the Mid to Late Triassic. The Carnian age determined for the marine faunas also coincides with a Triassic sea-level highstand (Haq et al., 1987). This can be correlated with marine evaporites described from the Halten Bank by Wiik-Jacobsen \& van Veen (1984), who postulated a seaway between Greenland and Norway in Norian times.

According to Doré (1991), the Røt Halite marks the first of a series of brief Triassic marine incursions into the southern North Sea domain from the Tethyan realm in the southeast. Subsidence at this time is correlative with an Early Triassic tectonic event in East Greenland (Seidler, 2000) as well as with the Hardegsen tectonic event in the southern North Sea (Trusheim, 1963). Any communication of standing water to the northern North Sea region in Early Triassic time was probably through the Central Graben and the Horn Graben (Fisher \& Mudge, 1998) and on through the Aasta Graben, Horda Platform area and Sogn Graben, as defined by Færseth (1996). Fischer et al. (2012) concluded that marine waters reached at least the southern part of the northern North Sea in Early Rhaetian time, causing brackish conditions due to fluvial discharge from the Fennoscandian High. Deegan \& Scull (1977) postulated that the Skagerrak Formation had evidence for occasional incursions of marine water.

\section{Could the re-distributed pyrite have been formed in brackish or marine water?}

Pyrite has been observed in the Lomvi Formation of wells NO 34/7-6 and NO 34/8-4S (Fig. 3D, E) and in the Lunde Formation of well GB 211/13-1 (Fig. 12D). It is also striking that re-distributed pyrite occurs at several levels in cores 3 and 4 (subaqueous) but not in cores 1 and 2 (subaerial) of well GB 211/13-1. Due to its irregular shape, the pyrite is interpreted to have been re-distributed, 
which means it must have been formed shortly after deposition and subsequently reworked. Sulphatereducing bacteria and organic material are needed in the formation of pyrite and anaerobic conditions are required for the process to take place. According to Berner (1984) pyrite formation in non-marine, freshwater sediments is severely limited by low concentrations of sulphate and this characteristic can be used to distinguish ancient organic-rich freshwater shales from marine shales. Also, Davison et. al. (1985) postulated that although there are high concentrations of acidic volatile sulphide in the near-surface sediments of productive lakes, very little is diagenetically converted to pyrite.

Could the re-deposited pyrite observed in the Lomvi and Lunde formations first have been deposited in marine or brackish water, and redistributed during storms and floods shortly after deposition? Is the presence of pyrite in cores 3 and 4 and not in cores 1 and 2 evidence for the presence of brackish or marine water during the deposition of cores 3 and 4 , while subaerial conditions (cores 1 and 2 ) were not favourable for formation of pyrite?

\section{Could the Lomvi Formation represent submerged lacustrine sand flats?}

O'Donnel (1993) interpreted clean sandstone units of Late Triassic age in the Beryl Embayment on the western edge of the Viking Graben to be submerged sand flats. The sandstone units showed wave-ripple lamination and extensive bioturbation, which was interpreted to suggest a shallow-water, lacustrine environment. The sediments of the Lomvi Formation, which also may be extensively bioturbated, may have been laid down in similar submerged sand flats.

\section{Could the Lomvi Formation in certain locations represent sabkha deposits?}

Lervik (1983) found that the Lomvi unit of well NO 33/12-5 contained evaporites - one of the few examples in all of the Triassic strata studied here. Cuttings samples there showed limited siliciclastic material and mostly white 'flour'-which was analysed and interpreted as an evaporite lithology. These evaporites could have formed in a playa lake or as coastal deposits. If formed in a playa lake, the Alke Formation should also have been dominated by evaporites but it contains only siliciclastic mud in all locations suggesting that the area was flooded after the deposition of the Lomvi Formation. The Lomvi Formation evaporites could represent near-shore sabkha deposits. In general, however, the lack of evaporites in the Triassic excludes the basin to be true playa type. The limited occurrence of evaporites within the mudstones in the northern North Sea may mean that freshwater and fine sediment supply exceeded evaporation at times (Hodgson et al., 1992)

\section{Were the depositional systems controlled by sea-level changes?}

The high gamma-ray readings at, e.g., $3540 \mathrm{~m}$ in well NO 33/12-5 in the upper part of the Alke Formation (Fig. 5A) reflect a maximum flooding zone along the base of a prograding system. From this depth upwards there is a coarsening-upward pattern to $3473 \mathrm{~m}$ which may mark where near-shore and delta-top facies prograded across the subaqueous facies of a water-filled basin. A similar transition is observed and interpreted in wells GB 211/13-1, GB 211/2-1, GB 211/07a-2 and GB 211/ 8a-2 (Fig. 5B). In GB 211/13-1, cores 3 and 4 located just above the Alke Formation are interpreted as 
near-shore strata while cores 1 and 2 are interpreted as alluvial delta-plain deposits, suggesting a similar subaerial over subaqueous progradation. The regional character of the pattern strongly suggests that the progradation was not into local water-filled ponds but was part of a major body of water periodically connected to the sea.

\section{Could the depositional systems of the Triassic have been similar to the present Gascoyne Delta?}

An analogue to the depositional setting of the Lunde and Skagerrak formations was suggested by a visit to the subaerial part of the Gascoyne delta system in western Australia. There, a rather straight river channel complex transports sediments from the source area during yearly flash floods. Enormous amounts of water are directed into the ephemeral river system during the seasonal flash floods. The main volume of the sediments is transported within the channel while large parts of the associated sub-environments are flooded. During the rest of the year the channel is dry, awaiting the next flooding. Fig. $12 \mathrm{C}$ shows a conceptual picture of Late Triassic palaeogeography during deposition of the Lunde and Skagerrak formations. Fig. 13A is a satellite photo from the Gascoyne River in western Australia (Google map) modified to fit the extent of of the Lunde Formation. Fig. 13B-E show sub-environments on the Gascoyne Delta to illustrate possible sub-environments present on the deltas in the northern North Sea during Late Triassic times. The envisaged depositional setting of the Lunde and Skagerrak systems appears similar to the Gascoyne Delta system. However, as discussed in the facies description of the Lunde Formation, there is not the same evidence for an ephemeral character for the depositional systems of the Lunde and Skagerrak formations. It may be that the river systems of the Lunde and Skagerrak formations were normally perennial as there is much evidence of year-round soil moisture. The northern North Sea depositional systems had much more restricted standing water areas to the west compared with the open ocean flanking Western Australia. 

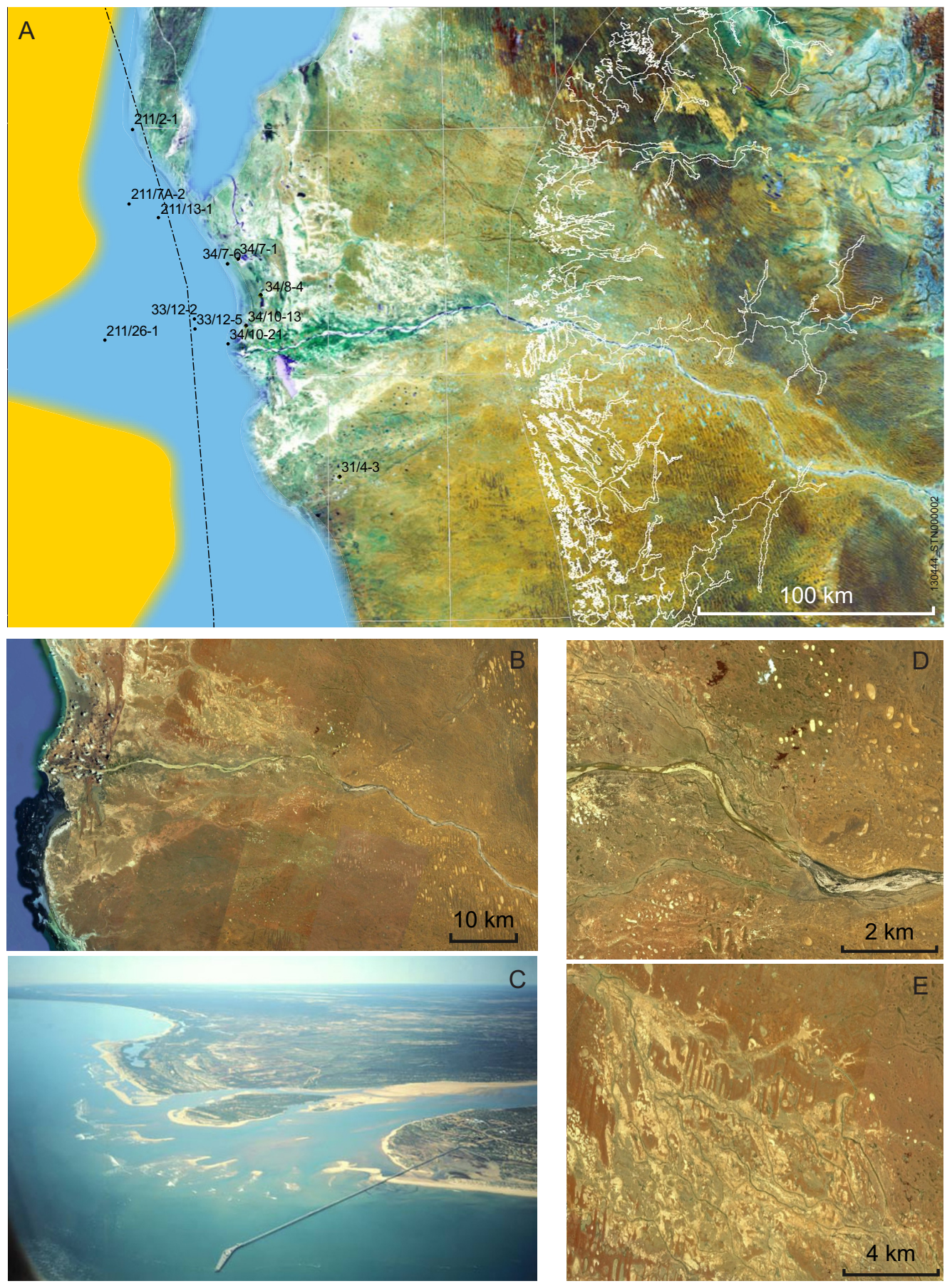

Figure 13. (A) The northern North Sea compared with the onshore Gascoyne delta area of Western Australia. The onshore Gascoyne delta is from a satellite photograph (Google map). The northern North Sea shows the interpreted depositional environment of the Lunde/Alke formations: subaerial regions equate with the Gascoyne delta; regions to the west are coloured blue (subaqueous areas) and yellow (possible subaerial region). (B-E) details of the Gascoyne delta. (B) Lower part of the Gascoyne River showing the central channel in the delta. (C) Gascoyne River delta and outlet (photograph from aeroplane taken by the author in 1986). (D) Close-up of (B) shows the main river channel and associated floodplain (E) Close-up of (B) shows floodplain. 


\section{Conclusions}

This paper is meant to be thought provoking, offering a challenge to look for more evidence to test the interpretations of the Triassic depositional setting developed here:

- The mudstones of the Smith Bank Formation were deposited as distal facies to proximal coarsegrained clastics after a period of regional subsidence in Early Triassic led to water filling the depressions.

- The Teist Formation reflects ephemeral depositional systems directed eastward to the deepest part of the basin, along the present-day west coast of Norway.

- The massive sandstones of the Lomvi Formation are interpreted as having been deposited on submerged flats in front of the deltas of the Lunde and Skagerrak formations.

- The mudstones of the Alke Formation were deposited subaqueously as distal fines in front of proximal sand systems of the Lunde and Skagerrak formations.

- The Lunde and Skagerrak formations represent the sediments of two major cones of deltaic systems derived from the Sognefjord and Hardangerfjord/Boknfjord areas. The area between the cones was dominated by finer-grained sediments and minor sand input. Similar input of sediments from the Moray Firth Basin and Scottish Highlands contributed to the basin fill from the west.

The depositional systems ended in basin water which periodically had marine incursions; direct evidence of marine water occurs in Early Norian strata. Further, there is circumstantial evidence that the depositional systems were controlled by sea level in a regional area. The overall conclusion is that geoscientists should look at the Triassic anew and integrate all data available in a regional context to test the suggestions drawn here.

Acknowledgements: I would like to thank Equinor for use of the well database and technical software to make overviews and correlations possible. Tony Spencer kindly improved the English language and text, and made many useful improvements to an early version of the manuscript. I would like to thank K. Bjørlykke and R. Steel for interesting discussions during my thesis upon which some of this work is based. Ron Steel is also thanked for useful suggestions to improvements of an early version of the paper. Rodmar Ravnås is thanked for constructive comments as referee. Further, I would like to thank several colleagues at Equinor for constructive discussions. S. Sande is thanked for drawing figures.

\section{References}

Andrews, S.D., Kelly, S.R.A., Braham, W. \& Kaye, M. 2014: Climatic and eustatic controls on the development of a Late Triassic source rock in the Jameson Land Basin, East Greenland. Journal of the Geological Society, London, 171, 609-619. https://doi.org/10.1144/jgs2013-075

Archer, S., Ward, S., Menad, S., Shahim, I., Grant, N., Sloan, H. \& Cole, A. 2010: The Jasmine discovery, Central North Sea, UKCS. In Vining, B. A. \& Pickering, S. C. (eds.) Petroleum Geology: From Mature Basins to New Frontiers-Proceedings of the 7th Petroleum Geology Conference, Geological Society, London, pp. 225-243. https://doi.org/10.1144/0070225

Bartolini, C., Malesani, P.G., Manetti, P. \& Wezel, F.C. 1975: Sedimentology and petrology of Quaternary sediments from the Hellenic Trench, Mediteranean Ridge and the Nile Cone from D.S.D.P., Leg 13, cores. Sedimentology 22, 205-236. https://doi.org/10.1111/j.1365-3091.1975.tb00291.x 
Berner, R. A. 1984: Sedimentary pyrite formation: An update. Geochimica et Cosmochimica Acta, 48, (4), 605-615. https://doi.org/10.1016/0016-7037(84)90089-9

Bugge, T., Ringaas, J. E., Leith, D. A., Mangerud, G., Weiss, H.M. \& Leith, T. 2002: Upper Permian as a new play model on the mid-Norwegian continental shelf: Investigated by shallow stratigraphic drilling. AAPG Bulletin 86/1, 107-127. https://doi.org/10.1306/61EEDA4E-173E-11D7-8645000102C1865D

Buatois, L.A., Santiago, N., Parra, K. \& Steel, R. 2008: Animal-Substrate Interactions in an Early Miocene Wave-Dominated Tropical Delta: Delineating Environmental Stresses and Depositional Dynamics (Tácata Field, Eastern Venezuela). Journal of Sedimentary Research 78/7, 458-479. https://doi.org/10.2110/jsr.2008.053

Cameron, T. D. J 1993: Triassic, Permian and pre-Permian of the central and northern North Sea. In Knox, R. W. O'B. and Cordey, W.G (eds.) Lithostratigraphic Nomenclature of the UK North Sea. British Geological Survey, Nottingham.

Cant, D.J. \& Walker R.G. 1976: Development of a braided-fluvial facies model for the Devonian Battery Point Sandstone, Quebec. Canadian Journal of Science, 13, 102-119. https://doi.org/10.1139/e76-010

Clemmensen, L. B. 1978: Alternating aeolian, sabkha and shallow lake deposits from the Middle Triassic Gipsdalen Formation, Scoresby Land, East Greenland. Palaeogeography, Palaeoclimatology, Palaeoecology 24, 11-135. https://doi.org/10.1016/0031-0182(78)90002-0

Clemmensen, L. B. 1980: Triassic rift sedimentation and paleogeography of central East Greenland. Grønlands Geologiske Undersøgelse. Bulletin 136, 1-72. https://doi.org/10.34194/bullggu.v136.6678

Davison, W., Lishman, J.P. \& Hilton, J. 1985: Formation of pyrite in freshwater sediments: Implications for C/S ratios. Geochimica et Cosmochimica Acta, 49, (7), 1615-1620.

https://doi.org/10.1016/0016-7037(85)90266-2

Deegan, C. E. \& Scull, B. J. (compilers) 1977: A proposed standard lithostratigraphic nomenclature for the central and northern North Sea. Reports Institute of the Geological Sciences. No. 77/25: Bulletin Norwegian Petroleum Directorate 1, Her Majesty's Stationary Office, London, 35 pp.

Doré, A. G. 1991: The structural foundation and evolution of Mesozoic seaways between Europe and the Arctic. Palaeogeography, Palaeoclimatology, Palaeoecology 87, 441-492. https://doi.org/10.1016/0031-0182(91)90144-G

Eide, F. 1989: Biostratigraphic correlation within the Triassic Lunde Formation in the Snorre Area. In Collinson, J.D. (ed.) Correlation in Hydrocarbon Exploration, Norwegian Petroleum Society, Graham and Trotman, London, pp. 291-297. https://doi.org/10.1007/978-94-009-1149-9_22

Fischer, J., Voigt, S., Franz, M., Schneider, J. W., Joachimski, M. M, Tichomirowa, M., Gøtze, J., \& Furrer, H. 2012: Palaeoenvironments of the Late Triassic Rhaetian Sea: implications from oxygen and strontium isotopes of hybodont shark teeth. Palaeogeography, Palaeoclimatology, Palaeoecology, 353-355, 60-72. https://doi.org/10.1016/j.palaeo.2012.07.002

Fisher, M. J. \& Mudge, D.C. 1998: Triassic. In Glennie, K. W. (ed.): Petroleum geology of the North Sea (4th ed). Blackwell, Oxford, pp. 212-244. https://doi.org/10.1002/9781444313413.ch7 
Frostick, L. E., Linsey, T. K. \& Reid, I. 1992: Tectonic and climatic control of Triassic sedimentation in the Beryl Basin, northern North Sea. Journal of the Geological Society 149, 13-26.

https://doi.org/10.1144/gsjgs.149.1.0013

Færseth, R. 1996: Interaction of Permo-Triassic and Jurassic extensional fault-blocks during the development of the northern North Sea. Journal of the Geological Society 153, 931-944.

https://doi.org/10.1144/gsjgs.153.6.0931

Goldsmith, P. J., Rich, B. \& Standring, J. 1995: Triassic correlation and stratigraphy in the southern Central Graben, UK North Sea. In Boldy, A. S. (ed.), Permian and Triassic Rifting in Northwest Europe, Geological Society Special Publication 91, pp. 123-143. https://doi.org/10.1144/GSL.SP.1995.091.01.07

Goldsmith, P. J, Hudson, G. \& van Veen, P. 2003: Triassic. In Evans, D. Graham, C., Armour, A. \& Bathurst, P. (eds.), The Millennium Atlas: Petroleum geology of the central and northern North Sea. The geological society of London, pp. 105-128.

Hardie, L.A. 1973: The alluvian fan-sabkha complex of northwest Gulf of California. Unpublished report to National Science Foundation, Washington, D.C.

Hardie, L. A., Smoot, J. P \& Eugster, H. P. 1978: Saline lakes and their deposits: A sedimentological approach. In Matter, A. \& Tucker, M. E. (eds.): Modern and ancient lake sediments. International Association of Sedimentologists, Special Publication 2, pp. 7-41.

https://doi.org/10.1002/9781444303698.ch2

Haq, B. V., Hardenbol, J. \& Vail, P. R. 1987: Chronology of fluctuating sea levels since the Triassic. Science 235, 1156-1167.

Hodgson, N. A., Farnsworth, J., \& Fraser, A. J. 1992: Salt-related tectonics, sedimentation and hydrocarbon plays in the Central Graben, North Sea, UKCS. In Hardman, R. F. P. (ed.) Exploration Britain: Geological Insights for the Next Decade. Geological Society, London, Special Publication, 67, pp. 31-63.

Jakobsson, K. H., Hamar, G. P., Ormaasen, D. E. \& Skarpnes, O. 1980: Triassic facies in the North Sea north of the Central Highs. The sedimentation of the North Sea. Norsk Petroleums Forening, XVIII, Geilo, 1-10.

Lang, S. C., Payenberg, T. H. D., Reilly, M. R. W., Hicks, T., Benson, J. \& Kassan, J. 2004: Modern analogues for dryland sandy fluvial-lacustrine deltas and terminal splay reservoirs. Australian Petroleum Production and Petroleum Association Journal, 44, pp 329-356. https://doi.org/10.1071/AJ03012

Lervik, K. S. 1983: Aspects of Triassic sedimentation and diagenesis of the Statfjord/Brent/Eider area in the northern North Sea. Cand. real. thesis, Univ. of Bergen.

Lervik, K. S. 2006: Triassic lithostratigraphy of the Northern North Sea Basin. Norwegian Journal of Geology 86, 93-116.

Lervik, K.S.; Spencer, A. M. \& Warrington, G. 1989: Outline of Triassic stratigraphy and structure in the central and northern North Sea. In Collinson, J.D. (ed.) Correlation in Hydrocarbon Exploration. Norwegian Petroleum Society, Graham and Trotman, London, pp. 173-189. https://doi.org/10.1007/978-94-009-1149-9_14 
Lucchitta, I. \& Suneson, N. 1981: Tertiary tectonic denudations of a Mesozoic- Early Tertiary gneiss (?) complex, Rawhide Mountains, western Arizona: Comment. Geology 9, 50-52.

https://doi.org/10.1130/0091-7613(1981)9\%3C50:CAROTT\%3E2.0.CO;2

McKie, T. 2014: Climatic and tectonic controls on Triassic dryland terminal fluvial system architecture, central North Sea. In Martinius, A.W., Ravnås, R., Howell, J.A., Steel, R.J. \& Wonham, J.P. (eds.) Depositional Systems to Sedimentary Successions on the Norwegian Continental Margin. International Association of Sedimentologists, Special Publications 26, pp. 53-85.

https://doi.org/10.1002/9781118920435.ch2

McKie, T. \& Williams, B. 2009: Triassic palaeogeography and fluvial dispersal across the northwest European Basins. Geological Journal 44, 711-741. https://doi.org/10.1002/gj.1201

McKie, T., Jolley, S. J. \& Kristensen, M. B. 2012: Stratigraphic and structural compartmentalization of dryland fluvial reservoirs: Triassic Heron Cluster, Central North Sea. In Jolley, S. J., Fisher, J., Ainsworth, R. B., Vroluk, P. J. \& Delisle, S. (eds.) Reservoir Compartmentalization. Geological Society, London, Special Publications, 347, pp. 165-198. https://doi.org/10.1144/SP347.11

Mearns, E.W., 1989: Neodymium isotope stratigraphy of Gullfaks Oil Field. In Collinson, J.D. (ed.), Correlation in Hydrocarbon Exploration, Norwegian Petroleum Society, Graham \& Trotman, London, pp. 201-215. https://doi.org/10.1007/978-94-009-1149-9_16

Mearns, E.W., Knarud, R., Ræstad, N., Stanley, K. \& Stockbridge, C. 1989: Samarium-Neodymium isotope stratigraphy of Snorre Oil Field. Journal of the Geological Society of London, 146, pp. 217-228. https://doi.org/10.1144/gsjgs.146.2.0217

Morad, S., de Ros, L. F., Nystuen, J. P. \& Bergan, M. 1998: Carbonate diagenesis and porosity evolution in sheet-flood sandstones: evidence from the middle and lower Lunde members (Triassic) in the Snorre Field, Norwegian North Sea. International Association of Sedimentologists, Special Publications 26, 53-85. https://doi.org/10.1002/9781444304893.ch3

Nielsen, L.H., 2003: Late Triassic-Jurassic development of the Danish Basin and the Fennoscandian Border Zone, southern Scandinavia. Geological Survey of Denmark and Greenland Bulletin 1, 459-526. https://doi.org/10.34194/geusb.v1.4681

Nøttvedt, A. \& Johannessen, E.P. 2013: Grunnlaget for Norges oljerikdom. Seinjura, et $\varnothing$ yhav vokser fram; 164-145 millioner år. In Ramberg, I.B., Bryhni, I., Nøttvedt, A. and Ragnes, K. (eds). Landet blir til-Norges geologi. Trondheim. Norsk geologisk forening, pp. 386-421.

Nystuen, J. P. \& Fält, L. M. 1995: Upper Triassic-Lower Jurassic reservoir rocks in the Tampen Spur area, Norwegian North Sea. In Hanslien, S. (ed.): Petroleum exploration and exploitation in Norway. Norwegian Petroleum Society Special Publication 4, Elsevier, Amsterdam, pp. 135-179.

https://doi.org/10.1016/S0928-8937(06)80041-X

Nystuen, J. P., Knarud, R., Jorde, K. \& Stanley, K. O. 1989: Correlation of Triassic to Lower Jurassic Sequences, Snorre Field and Adjacent Areas, Northern North Sea. In Collinson, J.D. (ed.) Correlation in Hydrocarbon Exploration. Norwegian Petroleum Society, Graham and Trotman, London, pp. 273-289. https://doi.org/10.1007/978-94-009-1149-9_21 
Nystuen, J. P., Kjemperud, A. V., Müller, R., Adestaal, V. \& Schomacker, E. R. 2014: Late Triassic to Early Jurassic climatic change, northern North Sea region: impact on alluvial architecture, palaeosols and clay mineralogy. In Martinius, A.W, Ravnaas, R., Howell, J. A., Steel, R. J. \& Wonham, J. P. (eds.). Depositional Systems to Sedimentary Successions on the Norwegian Continental Shelf. International Association of Sedimentologists, Special Publications 46, pp. 59-100. https://doi.org/10.1002/9781118920435.ch3

O'Donnel, D. 1993: Enhancing the Oil Potential of Secondary Triassic Reservoirs in the Beryl A Field, UK North Sea. In Spencer, A.M. (ed). Generation,Accumulation and Production of Europe's Hydrocarbons III. Special Publication of the European Association of Petroleum Geoscientists No. 3. Springer Verlag Berlin Heidelberg 1993, pp. 37-44. https://doi.org/10.1007/978-3-642-77859-9_3

Olsen, J. C., 1983: The structural outline of the Horn Graben. Geologie en Mijnbow 62, 47-50. https://doi.org/10.1007/978-94-009-5532-5_4

Ramberg, I. B. \& Morgan, P. 1984: Physical characteristics and evolutionary trends of continental rifts. Tectonics 7, 165-216.

Rhys, G. H. (compiler) 1974: A proposed standard lithostratigraphic nomenclature for the southern North Sea and an outline structural nomenclature for the whole of the (UK) North Sea. Report Institute Geological Science Committee on North Sea, 74/8, 14 pp.

Ryseth, A. 2001: Sedimentology and palaeogeography of the Statfjord Formation (Rhaetian to Sinemurian) North Sea. In Martinsen, O. J. \& Dreyer, T. (eds.) Sedimentary Environments offshore Norway- Paleozoic to Recent. Special Publication of the Norwegian Petroleum Society 10. Amsterdam, Elsevier, pp. 67-85. https://doi.org/10.1016/S0928-8937(01)80009-6

Ryseth, A. \& Ramm, M. 1996: Alluvial architecture and differential subsidence in the Statfjord Formation, North Sea: prediction of reservoir potential. Petroleum Geoscience 2, 271-287. https://doi.org/10.1144/petgeo.2.3.271

Røe, S. \& Steel, R. 1985: Sedimentation, sea level rise and tectonics at the Triassic-Jurassic boundary (Statfjord Formation), Tampen Spur, northern North Sea. Journal of Petroleum Geology 8/2, 163-186. https://doi.org/10.1111/j.1747-5457.1985.tb01009.x

Seidler, L. 2000: Incised submarine canyons governing new evidence of Early Triassic rifting in East Greenland. Paleogeography, Paleoclimathology, Paleoecology 6, 267-293.

https://doi.org/10.1016/S0031-0182(00)00126-7

Seidler, L., Steel, R., Stemmerik, L. \& Surlyk, F. 2004: North Atlantic marine rifting in the Early Triassic: new evidence from East Greenland. Journal of the Geological Society of London, 161, 583-592. https://doi.org/10.1144/0016-764903-063

Stanley, K.O., Jorde, K., Raestad, N. \& Stockbridge, C.P, 1990: Stochastic modelling of reservoir sand bodies for input to reservoir simulation, Snorre Field, northern North Sea, Norway. In Buller, A.T, Berg, E., Hjelmeland, O., Torsaeter, O. \& Aasen, J.O. (eds.). North Sea oil \& gas reservoirs-II. Graham \& Trotman, London, pp. 91-101. https://doi.org/10.1007/978-94-009-0791-1_5

Steel, R. J. 1990: Triassic-Jurassic megasequence stratigraphy in the northern North Sea: rift to post-rift evolution. Petroleum Geology of Northwest Europe, Proceedings of the 4th Conference. Geological Society London, 1, 299-315. https://doi.org/10.1144/0040299 
Steel, R. \& Ryseth, A. 1990: The Triassic-Early Jurassic succession in the northern North Sea: megasequence stratigraphy and intra-Triassic tectonics. In Hardman, R P. F. \& Brooks, J. (eds.). Tectonic events responsible for Britain's Oil and Gas reserves. Geological Society, London, Special Publication 55, 139-168. https://doi.org/10.1144/GSL.SP.1990.055.01.07

Trusheim, F. 1963: Zur Gliederung des Buntsandsteins. Erdøl-Zeitschrift fur Bohr und Førdertechnik 79, pp. 277-292.

Vollset, J. \& Doré, A.G. 1984: A revised Triassic and Jurassic lithostratigraphic nomenclature for the Norwegian North Sea. Norwegian Petroleum Directorate Bulletin 3, 53 pp.

Wiik-Jacobsen, V. \& Veen, P. van 1984: The Triassic offshore Norway north of 62 degrees north. In Spencer, A. M. (ed.). Petroleum geology of the North European Margin. Norwegian Petroleum Society Graham and Trotman, 1984, pp. 317-327. https://doi.org/10.1007/978-94-009-5626-1_23 